\title{
Trapping of a Ruthenium-Butatrienylidene Intermediate by Tertiary Amines. 2-Ammoniobutenynyl Complexes ${ }^{\dagger}$
}

\author{
Rainer F. Winter* and F. M. Hornung ${ }^{\ddagger}$ \\ Institut für Anorganische Chemie, Universität Stuttgart, Pfaffenwaldring 55, \\ D-70569 Stuttgart, Germany
}

Received May 3, 1999

\begin{abstract}
2-Ammoniobutenynyl Ru-complexes trans- $\left[\mathrm{Cl}(\mathrm{dppm})_{2} \mathrm{Ru}-\mathrm{C} \equiv \mathrm{C}-\mathrm{C}\left(\mathrm{NR}_{2} \mathrm{R}^{\prime}\right)=\mathrm{CH}_{2}\right]^{+} \mathrm{PF}_{6}{ }^{-}(3 \mathrm{a}-$ g) have been prepared in a one-pot procedure from cis-[RuCl$\left.{ }_{2}(\mathrm{dppm})_{2}\right]$, excess butadiyne, and various tertairy amines, whereas 4-(dimethylamino)pyridine binds to the unsaturated carbon ligand via the pyridine nitrogen to give $\mathbf{3 h}$. These results may be rationalized by envoking the butatrienylidene complex trans-[Cl(dppm $\left.)_{2} \mathrm{Ru}=\mathrm{C}=\mathrm{C}=\mathrm{C}=\mathrm{CH}_{2}\right]^{+}$as the reactive intermediate. Amine complexes cis-[Ru(dppm $\left.)_{2} \mathrm{Cl}\left(\mathrm{NR}_{2} \mathrm{R}^{\prime}\right)\right]^{+}$are frequently formed as side products and the 4-dimethylaminopyridine derivative cis-[Ru(dppm) $\left.{ }_{2} \mathrm{Cl}(4-\mathrm{DMAP})\right]^{+}$was obtained in high yield in the absence of butadiyne but under otherwise identical reaction conditions. Complexes 3 have been characterized by various spectroscopic and el ectrochemical techniques including cyclic and square wave voltammetry and, in the case of the $\mathrm{NEt}_{3}$ derivative $\mathbf{3 a}$, also by X-ray crystallography. Most complexes $\mathbf{3}$ undergo a fully reversible one-electron oxidation at half-wave potentials that depend on the amine substituent. This provides evidence for delocalization over the conjugated $C_{3}$ bridge. EPR spectroscopic investigations of the oxidized forms of the $\mathrm{NEt}_{3}$ and $\mathrm{PhCH}_{2} \mathrm{NMe}_{2}$ derived complexes $3 \mathrm{a}$ and $3 f$ point to Ru-centered radical dications. The irreversible reduction of complexes $\mathbf{3}$ occurs in two closely spaced, poorly defined waves and ultimately rel eases the respective free amine, which itself is reactive toward the Ru(III) oxidation product. Following the oxidation of $\mathbf{3 a}$ and $\mathbf{3 f}$ by UV/vis and IR spectroelectrochemistry revealed a blue shift of the prominent absorption band and a bleaching of the $\mathrm{C} \equiv \mathrm{C}$ stretch.
\end{abstract}

\section{Introduction}

Considerable progress has been achieved in attaching more extended cumulenic systems to transition metal centers, which also serve to stabilize these otherwise highly reactive $C_{n} R_{2}$ species. In 1982 Selegue et al. reported that propargylic alcohols may be activated in the presence of coordinatively unsaturated Ru precursors to give substituted allenylidene complexes. ${ }^{1} \mathrm{Fol}$ lowing this protocol, a large number of novel allenylidene complexes of mainly group 8 and 9 metals have been prepared. ${ }^{2-4}$ As these species were now readily available in large quantities, a rich chemistry of the

\footnotetext{
* Corresponding author. E-mail: winter@iac.uni-stuttgart.de.

† Dedicated to Professor Helmut Werner on the occasion of his 65th birthday.

$¥ X$-ray structure analysis.

(1) Selegue, J. P. Organometallics 1982, 1, 217.

(2) (a) Wolinska, A.; Touchard, D.; Dixneuf, P. H.; Romero, A. J . Organomet. Chem. 1991, 420, 216. (b) Touchard, D.; Pirio, N.; Toupet, L.; Fettouhi, M.; Ouahab, L.; Dixneuf, P. H. Organometallics 1995, 14, 5263. (c) Touchard, D.; Guesmi, S.; Bouchaib, M.; Haquette, P.; Daridor, A.; Dixneuf, P. H. Organometallics 1996, 15, 2579. (d) Werner, H.; Stark, A.; Steinert, P.; Grünwald, C.; Wolf, J. Chem. Ber. 1995, 128 , 49. (e) Esteruelas, M. E.; Gómez, A. V.; Lahoz, F. J .; Oñate, E.; Oro, L. A. Organometallics 1996, 15, 3423. (g) Tamm, M.; J entzsch, J .; Werncke, W. Organometallics 1997, 16, 1418.

(3) (a) Cadierno, V.; Gamasa, M. P.; Gimeno, J .; Gonzáles-Cueva, M.; Lastra, E.; Borge, J .; García-Granda, S.; Pérez-Carreño, E. Organometallics 1996, 15, 2137. (b) Bohanna, Callejas, B.; Edwards, A. J .; Esteruelas, M. A.; Lahoz, F. J .; Oro, L. A.; Ruiz, N.; Valero, C. Organometallics 1998, 17, 373. (c) Crochet, P.; Esteruelas, M. A.; López, Ruiz, N.; Tolosa, J . I. Organometallics 1998, 17, 3479.
}

allenylidene ligand has developed, its reactivity patterns being dominated by the alternating electron-poor and electron-rich carbon centers as one moves along the cumulated chain. ${ }^{3 a, 5,6}$ Thus, nucleophiles attack the metal-bonded $\mathrm{C}_{\alpha}$ or $\mathrm{C}_{\gamma}$, depending on the degree of steric protection by the ancillary ligands and the electronic properties of both the metal fragment and the nucleophile, ${ }^{2 b, e, 3 b, 6-10}$ while electrophiles such as $\mathrm{H}^{+}$add to the $\beta$-C atom. ${ }^{3 c, 11}$ The synthetic use of Ru-allenylidene complexes is highlighted by their recent application to ring-closing metathesis (RCM) as discovered by Fürstner, Dixneuf, and Hill.12 In another line of progress, extension of this chemistry to diynols yielded the first

(4) (a) Werner, H.; Rappert, T.; Wiedemann, R.; Wolf, J .; Mahr, N. Organometallics 1994, 13, 2721. (b) Martín, Gevert, O.; Werner, H. J . Chem. Soc., Dalton Trans. 1996, 2275. (c) Esteruelas, M. A.; Oro, L. A.; Schrickel, Organometallics 1997, 16, 796.

(5) (a) Kostic, N. M.; Fenske. R. F. Organometallics 1982, 1, 974 (b) Schilling, B. E. R.; Hoffmann, R.; Lichtenberger, D. L. J . Am. Chem. Soc. 1979, 101, 585.

(6) (a) Cadierno, V.; Gamasa, M. P.; Gimeno, J .; López-González, Borge, J .; García-Granda, Organometal lics 1997, 16, 4453. (b) Esteruelas, M. E.; Gómez, A. V.; Lopez, A. M.; Modrego, J .; Oñate, E. Organometallics 1997, 16, 5826.

(7) (a) Cadierno, V.; Gamasa, M. P.; Gimeno, J .; Lastra, E. J Organomet. Chem. 1994, 474, C27. (b) Cadierno, V.; Gamasa, M. P.; Gimeno, J.; Borge, J.; García-Granda, S. J. Chem. Soc., Chem Commun. 1994, 2495. (c) Gamasa, M. P.; Gimeno, J .; GonzálezBernardo, Borge, J. García-Granda, Organometallics 1997, 16, 2483. (d) Cadierno, V.; Gamasa, M. P.; Borge, J . Organometallics 1997, 16, 3178. (e) Cadierno, V.; Gamasa, M. P.; Gimeno, J .; Pérez-Carreño, E . I enco, E. Organometallics 1998, 17, 5216. 
stable pentatetraenylidene complexes. ${ }^{13,14}$ Steric protection of the cumulated $\mathrm{C}_{5}$ ligand by bulky aryl substituents rendered these complexes stable enough for crystallographic determinations of their molecular structures. Likewise, the addition of a tris(dimethylamino)stabilized diacetylide $C_{5}$ chain with subsequent abstraction of one of the $\mathrm{NMe}_{2}$ groups led to bis(dimethylamino)substituted pentatetraenylidene complexes of chromium and tungsten. These exhibit a considerable bond length alternation within the unsaturated ligand. ${ }^{15} \mathrm{~A}$ higher homol ogue of the latter was, however, only obtained as an intermediate starting from the respective $C_{7}$ precursor. ${ }^{16}$ An authoritative review covering this area has just been published. ${ }^{17}$

In contrast, reports on cumulenylidene ligands comprising an even number of carbon atoms greater than 2 are much more scarce. Compounds with a butatrienylidene ligand linking two metal centers have been isolated by deprotonation of vinyl-bridged bis(carbyne) complexes of molybdenum and tungsten ${ }^{18}$ or oxidation of diynediyl-bridged neutral $\mathrm{Re}^{19}$ or $\mathrm{Ru}^{20}$ complexes. Very recently, Lapinte and co-workers also reported diiron complexes $\left[\left\{\mathrm{Cp}^{*} \mathrm{~L}_{2} \mathrm{Fe}\right\}=\mathrm{C}=\mathrm{C}=\mathrm{C}=\mathrm{C}(\mathrm{R})\left\{\mathrm{Fe}\left(\mathrm{CO}_{2}\right)\right.\right.$ -

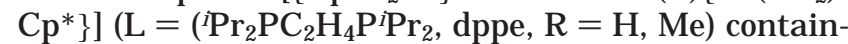
ing secondary or tertiary butatrienylidene ligands formed upon protonation or methylation of the diynediylbridged precursor. ${ }^{21} \mathrm{Also}, \mathrm{Ru}_{5}$ clusters where a $\mathrm{C}_{4} \mathrm{RH}$

(8) (a) Pirio, N.; Touchard, D.; Dixneuf, P. H. J . Chem. Soc., Chem. Commun. 1991, 980. (b) Pirio, N.; Touchard, D.; Dixneuf, P. H. J. Organomet. Chem. 1993, 462, C18. (c) Touchard, D.; Pirio, N.; Dixneuf, P. H. Organometallics 1995, 14, 4920. (d) Esteruelas, M. E.; Gómez, A. V.; López, A. M.; Puerta, M. C.; Valerga, P. Organometallics 1998, 17, 4959. (e) Esteruelas, M. E.; Gómez, A. V.; López, A. M.; Modrego, $\mathrm{J}$.; Oñate, E. Organometallics 1998, 17, 5434.

(9) (a) Werner, H.; Wiedemann, R.; Laubender, M.; Wolf, J .; Windmüller, B. J . Chem. Soc., Chem. Commun. 1996, 1413. (b) Werner, H. Wiedemann, R.; Steinert, P.; Wolf, J . Chem. Eur. J . 1997, 3, 127. (c) Laubender, M.; Werner, H. Angew. Chem. 1998, 110, 158.

(10) (a) Le Bozec; H.; Ouzzine, K.; Dixneuf, P. H. J . Chem. Soc., Chem. Commun. 1989, 219. (b) Pilette, D.; Ouzzine, K.; Le Bozec, H.; Dixneuf, P. H.; Rickard, C. E. F.; Roper, W. E. Organometallics 1992, 11, 809. (c) Touchard, D.; Pirio, N.; Dixneuf, P. H. Organometallics 1995, 14, 4920 .

(11) Kol obova, N. E.; I vanov, L. L.; Zhvanko, O. S.; Khitrova, O. M.; Batsanov, A. S.; Struchkov, Yu. T. J . Organomet. Chem. 1989, 379, 303.

(12) (a) Fürstner, A.; Picquet, M.; Bruneau, C.; Dixneuf, P. H. J . Chem. Soc., Chem. Commun. 1998, 1315. (b) Picquet, M.; Bruneau C.; Dixneuf, P. H. J . Chem. Soc., Chem. Commun. 1998, 2249. (c) Fürstner, A.; Ackermann, L. J . Chem. Soc., Chem. Commun. 1999, 95. (d) Picquet, M.; Touchard, D.; Dixneuf, P. H. New J . Chem. 1999, 141. (e) Harlow, K. J.; Hill, A. F.; Wilton-Ely, J. D. E. T. J . Chem. Soc., Dalton Trans. 1999, 285. (f) Fürstner, A.; Hill, A. F.; Liebl, M.; Wilton-Ely, J. D. E. T. Chem. Soc., Chem. Commun. 1999, 601. (g) Picquet, M.; Touchard, D.; Bruneau, C.; Dixneuf, P. H. New J . Chem. 1999, 141.

(13) (a) Romero, A.; Peron, D.; Dixneuf, P. H. J . Chem. Soc., Chem. Commun. 1990, 1410. (b) Touchard, D.; Haquette, P.; Daridor, A.; Toupet, L.; Dixneuf, P. H. J . Am. Chem. Soc. 1994, 116, 11157.

(14) (a) Lass, R. W.; Steinert, P.; Wolf, J .; Werner, H. Chem. Eur. J . 1996, 2, 19. (b) Kovacik, I.; Laubender, M.; Werner, H. Organome tallics 1997, 16, 5607.

(15) (a) Roth, G.; Fischer, H. Organometallics 1996, 15, 1139. (b) Roth, G.; Fischer, H.; Meyer-Friedrichsen, T.; Heck, J .; Houbrechts, S.; Persoons, A. Organometallics 1998, 17, 1511.

(16) Roth, G.; Fischer, H. Organometallics 1996, 15, 5766.

(17) Bruce, M. I. Chem. Rev. 1998, 98, 2599.

(18) Woodworth, B. E.; White, P. S.; Templeton, J . L. J . Am. Chem. Soc. 1997, 119, 828.

(19) Bruce, M. I.; Denisovich, L. I.; Peregudova, S. M.; Ustynyuk, N. A. Mendeleev Commun. 1996, 200.

(20) (a) Seyler, J. W.; Weng, W.; Zhou, Y.; Gladysz, J . A. Organometallics 1993, 12, 3802. (b) Zhou, Y.; Seyler, J. W.; Weng, W.; Arif, A. M.; Gladysz, J. A. J . Am. Chem. Soc. 1993, 115, 8509. (c) Brady, M.; Weng, W.; Zhou, Y.; Seyler, J. W.; Amoroso, A. J .; Arif, A. M.; Böhme, M.; Frenking, G.; Gladysz, J . A. J . Am. Chem. Soc. 1997, 119, 775.
$\left(\mathrm{R}=\mathrm{SiMe}_{3}, \mathrm{H}\right.$ ) ligand additionally employs two of its $\mathrm{C}=\mathrm{C} \pi$ bonds for side-on coordination and thus acts as a six-electron donor are known. ${ }^{22}$ Comparable mononuclear complexes are still elusive. Moreover, our knowledge of mononuclear complexes is restricted to butatrienylidene intermediates of iron and ruthenium. Selegue generated a first example by addition of trifluoroacetic acid anhydride to a coordinated alkynyl ketone. ${ }^{23}$ A different approach was utilized by Bruce ${ }^{24}$ and Winter, ${ }^{25}$ who applied the well-known Ru-mediated terminal alkyne to vinylidene tautomerization ${ }^{4 a, 26}$ to butadiyne (or diacetylene) as the conceptionally simplest diyne derivative. More recently, this protocol has been applied to other terminal diynes $\mathrm{RC}_{4} \mathrm{H}\left(\mathrm{R}=\mathrm{Ph}^{27}\right.$ $\mathrm{SiMe}_{3}{ }^{28}$ ).

Due to the highly reactive nature of these still elusive butatrienylidene intermediates, no reports on their direct spectroscopic observation have appeared. Trapping reactions, however, lend convincing support to their presence, at least as the reactive species in an equilibrium. Again, the reactivity of the cumulated $\mathrm{C}_{4}$ ligand is explained by alternating electron-poor and electronrich carbon centers along the cumulated chain. Two major reaction types have been found so far: (i) the regioselective addition of protic nucleophiles to the terminal $\mathrm{C}_{\gamma}-\mathrm{C}_{\delta}$ double bond to give methyl-substituted allenylidene complexes $23 a, c, 27,28$ and (ii) the regioselective addition of aprotic nucleophiles to the electron-deficient $\mathrm{C}_{\gamma}, \mathrm{C}_{\alpha}$ being sterically protected by bulky phosphine coligands on $\mathrm{Ru}$. ${ }^{24 a, c, 25}$ These trapping reactions allow the $\mathrm{C}_{4} \mathrm{H}_{2}$ unit to be incorporated into highly unsaturated and functionalized yet stable ligands. In a previous communication we have reported on the trapping of the $\left[\mathrm{Cl}(\mathrm{dppm})_{2} \mathrm{Ru}=\mathrm{C}=\mathrm{C}=\mathrm{C}=\mathrm{CH}_{2}\right]^{+}$intermediate by tertiary amines to give 2-ammoniobutenynyl complexes. ${ }^{25 a}$ It is here that we give a full account of this work, including electrochemical studies and the spectroscopic characterization of some of the dications resulting from the in situ electrochemical oxidation of the Ru(II) monocations.

\section{Results and Discussion}

Upon treating a pale yellow suspension of cis- $\mathrm{RuCl}_{2-}$ $(\mathrm{dppm})_{2}(\mathbf{1})$ and a mild halide-abstracting reagent like $\mathrm{NaPF}_{6}$ or $\mathrm{NaSbF}_{6}$ in either $\mathrm{CH}_{2} \mathrm{Cl}_{2}$ or chlorobenzene $(\mathrm{PhCl})$ with excess butadiyne, an intense blue-green

(21) Coat, F.; Guillemot, M.; Paul, F.; Lapinte, C. J . Organomet. Chem. 1999, 578, 76 .

(22) Adams, C. J .; Bruce, M. I.; Skelton, B. W.; White, A. H. J . Chem. Soc., Chem. Commun. 1996, 2663.

(23) Lomprey, J. R.; Selegue, J. P. Organometallics 1993, 12, 616.

(24) (a) Bruce, M. I.; Hinterding, P.; Low, P. J .; Skelton, B. W. White, A. H. J . Chem. Soc., Chem. Commun. 1996, 1009. (b) Bruce, M. I.; Hinterding, P.; Ke, M.; Low, P. J ;; Skelton, B. W.; White, A. H. J . Chem. Soc., Chem. Commun. 1997, 715. (c) Bruce, M. I.; Hinterding, P.; Low, P.J .; Skelton, B. W.; White, A. H.J . Chem. Soc., Dalton Trans. 1998, 467

(25) (a) Winter, R. F.; Hornung F. M. Organometallics 1997, 16, 4248. (b) Winter, R. F. J'. Chem. Soc., Chem. Commun. 1998, 2209.

(26) (a) Lomprey, J . R.; Selegue, J . P. J . Am. Chem. Soc. 1992, 114 5518. (b) Bullock, R. M. J . Chem. Soc., Chem. Commun. 1989, 165. (c) Haquette, P.; Pirio, N.; Toupet, L.; Dixneuf, P. H. J . Chem. Soc., Chem. Commun. 1993, 163. (d) Touchard, D.; Haquette, P.; Pirio, N.; Toupet, L.; Dixneuf, P. H. Organometallics 1993, 12, 3132. (d) Whittall, I. R Humphrey, M. G.; Hockless, D. C. R.; Skelton, B. W.; White, A. H. Organometallics 1995, 14, 3970. (e) de los Ríos, I.; J iménez-Tenorio, M.; Puerta, M. C.; Valerga, P. J . Am. Chem. Soc. 1997, 119, 6529.

(27) Haquette, P.; Touchard, D.; Toupet, D.; Dixneuf, P. J . Organomet. Chem. 1998, 565, 67.

(28) Guillaume, V.; Thominot, P.; Coat, F.; Mari, A.; Lapinte, C. J Organomet. Chem. 1998, 565, 75. 
Scheme 1

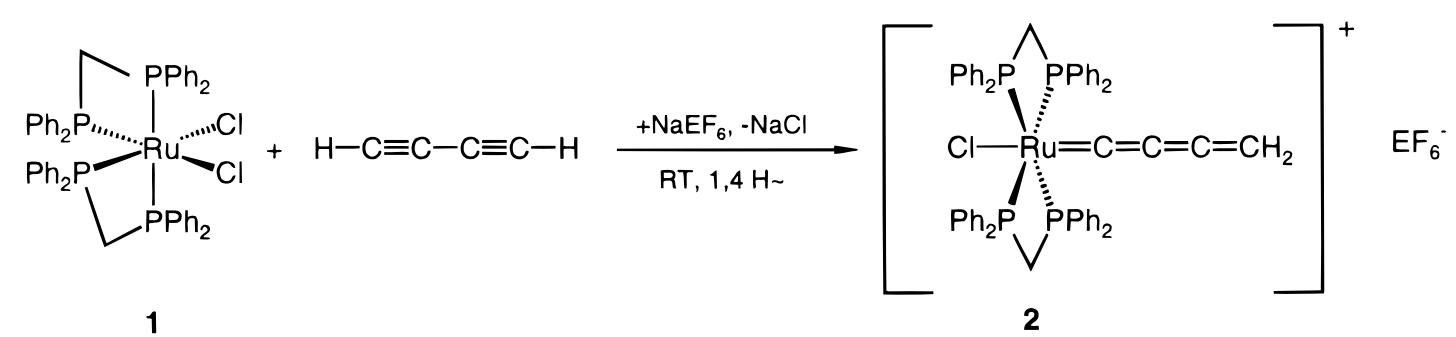

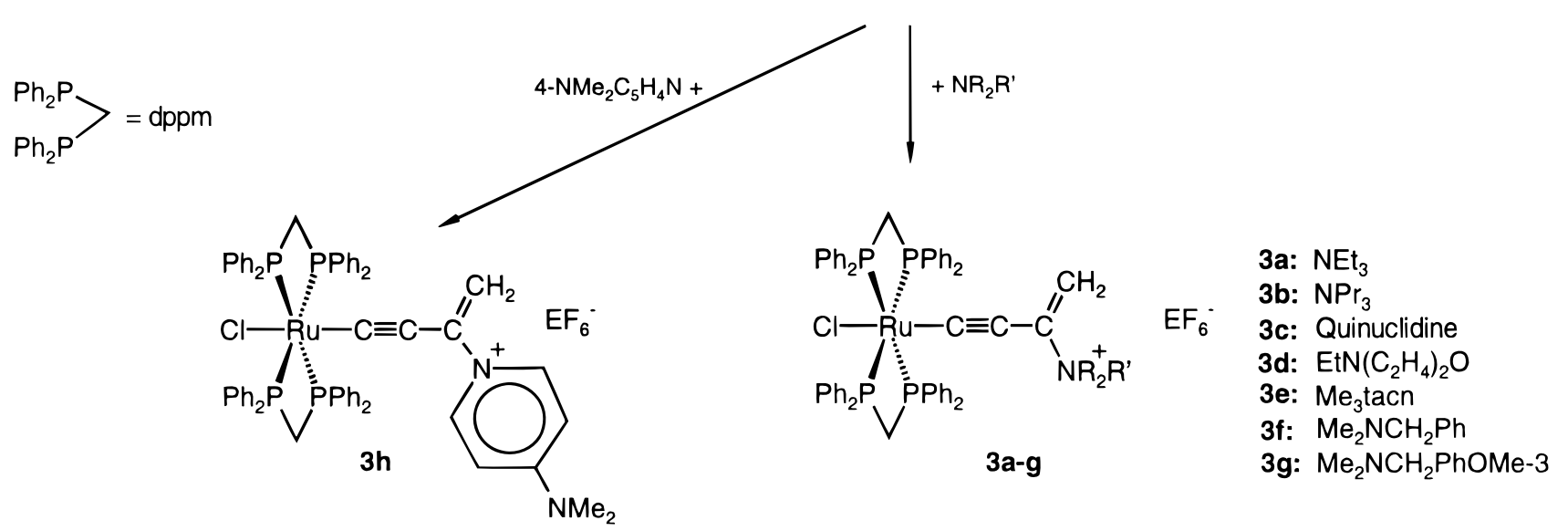

Scheme 2

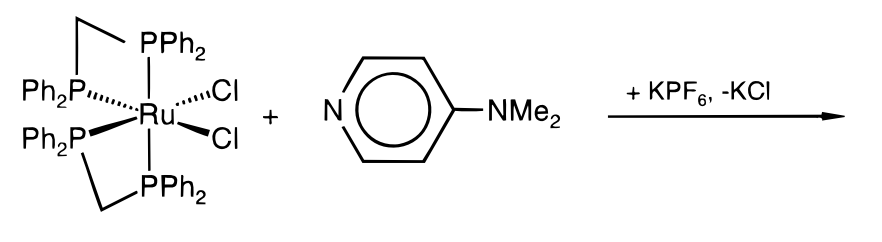

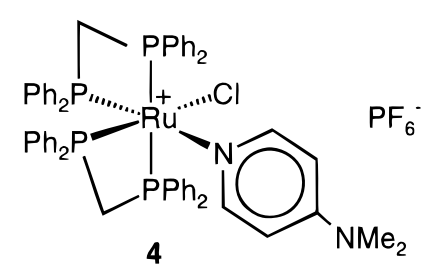

solution that exhibits a strong broad absorption band in the IR $\left(\mathrm{CH}_{2} \mathrm{Cl}_{2}, \tilde{v}=1891 \mathrm{~cm}^{-1}\right.$; $\left.\mathrm{PhCl}, \tilde{v}=1898 \mathrm{~cm}^{-1}\right)$ is gradually formed. Following this reaction by means of ${ }^{31} \mathrm{P}$ NMR spectroscopy reveals that at this stage several individual compounds are present besides unreacted starting material, and complex product mixtures are obtained if no trapping reagent is added. No pure materials could be obtained from such solutions. In the presence of 2-6 equiv of tertiary amines, however, the product mixtures turn much more uniform and the 2-ammoniobutenynyl complexes $\mathbf{3 a} \mathbf{3} \mathbf{3 g}$ are obtained in good to moderate yields after chromatographic workup (Scheme 1). The progress of these reactions is conveniently followed by the rise of the absorption of the new $\mathrm{C} \equiv \mathrm{C}$ triple bond in $\mathbf{3}$. More efficient halide-abstracting agents such as silver or thallium salts led to much faster reactions but to considerable loss of selectivity, thus complicating the workup and diminishing the isolated yields. These metal ions are known to possess some affinity to the $\mathrm{C} \equiv \mathrm{C}$ triple bond and may therefore interfere by coordinating to the unsaturated ligand. ${ }^{29}$ This reaction seems to be fairly general for saturated al iphatic or benzylic amines with relatively little steric bulk. Aniline derivatives such as $\mathrm{N}, \mathrm{N}$-diethylaniline, p-toluidine, or N,N-2,4,6-pentamethylaniline gave no isolable products with the exception of 4-(dimethylamino)pyridine (4-DMAP), which yields derivative $3 \mathbf{h}$. According to spectroscopy, this ambident nucleophile is, however, attached to the carbon chain via the pyridine nitrogen rather than the amino group (vide infra). Ether functionalities (3d) are tolerated while allylic or propargylic moieties give rise to a [3,3] sigmatropic isomerization process of the initial addition products. ${ }^{25 a}$ Two detrimental side reactions were, however, encountered in these transformations: (i) The added amine is also a potent ligand which may compete with butadiyne for the coordinatively unsaturated $\left[\mathrm{CIRu}(\mathrm{dppm})_{2}\right]^{+}$intermediate. Thus, small amounts of cis-[Ru(dppm $)_{2} \mathrm{Cl}$ $\left.\left(\mathrm{NR}_{2} \mathrm{R}^{\prime}\right)\right]^{+}$were frequently detected as side products by 31P N MR spectroscopy of the crude product mixtures by virtue of their characteristic ACXY spin systems. Among the amines investigated in this study, ethylmorpholine, quinuclidine, and 4-DMAP were especially prone to this reaction. This is highly reminiscent of the easy dissociation of chloride from $\mathbf{1}$ in acetonitrile solution. ${ }^{30} \mathrm{Re}$ markably, such a complex was the only product observed for 4-dimethylaminobenzonitrile (two isomers arising from the coordination of either the nitrile or the amino function to $\left.\left[\mathrm{ClRu}(\mathrm{dppm})_{2}\right]^{+}\right)$in $\mathrm{PhCl}$. As a final proof, cis-[Ru(dppm) $\left.)_{2} \mathrm{Cl}(4-\mathrm{DMAP})\right]^{+} \mathrm{PF}_{6}{ }^{-}$(4) was synthesized in high yield from $1, \mathrm{KPF}_{6}$, and 4-DMAP under otherwise identical conditions but in the absence of butadiyne (Scheme 2). The amount of such products could be minimized when a high excess of butadiyne and smaller amounts of the respective amines were employed. (ii) Another complication arises from the inher-

(29) (a) de los Ríos, I.; J iménez-Tenorio, M.; Puerta, M. C.; Valerga, P. Organometallics 1998, 17, 3356. (b) Zhu, Y.; Wolf, M. O.; Yap, G. P. A. I norg. Chem. 1997, 36, 5483.

(30) Sullivan, B. P.; Meyer, T. J . Inorg. Chem. 1989, 21, 1037. 
Table 1. Spectroscopic Data for 2-Ammoniobutenynyl Complexes 3

\begin{tabular}{|c|c|c|c|c|c|c|c|c|c|c|c|}
\hline \multirow[b]{3}{*}{ amine/complex } & \multirow{3}{*}{$\begin{array}{l}\mathrm{IR}^{\mathrm{a}}\left(v_{\mathrm{C}} \equiv \mathrm{C}\right) \\
{\left[\mathrm{cm}^{-1}\right]}\end{array}$} & \multirow[b]{3}{*}{${ }^{31} \mathrm{P}\left\{{ }^{1} \mathrm{H}\right\}^{\mathrm{b}}$} & \multirow{2}{*}{\multicolumn{2}{|c|}{${ }^{1} \mathrm{H}^{\mathrm{b}}$}} & \multirow{2}{*}{\multicolumn{4}{|c|}{${ }^{13} \mathrm{C}$}} & \multicolumn{3}{|c|}{$\operatorname{UV} / \operatorname{vis}\left(\lambda_{\max }\left(\log \epsilon_{\max }\right)\right)$} \\
\hline & & & & & & & & & & & \\
\hline & & & vinyl-H & $\mathrm{J}[\mathrm{Hz}]$ & $\mathrm{C}_{\alpha}(\mathrm{P}-\mathrm{C})$ & $\mathrm{C}_{\beta}(\mathrm{P}-\mathrm{C})$ & $\mathrm{C}_{\gamma}$ & $\mathrm{C}_{\delta}$ & $\mathrm{CH}_{3} \mathrm{CN}$ & $\mathrm{CH}_{2} \mathrm{Cl}_{2}$ & {$\left[\mathrm{~cm}^{-1}\right]$} \\
\hline $\mathrm{NEt}_{3}, \mathbf{3 a}$ & 2032 & -5.8 & $4.60,3.80$ & 3.04 & $146.2(14.0)^{c}$ & 100.0 & 53.8 & 111.4 & $312(3.88)$ & 319 (3.92) & 700 \\
\hline $\mathrm{NPr}_{3}, \mathbf{3 b}$ & 2027 & -4.1 & $4.68,4.12$ & 2.88 & $146.0(14.6)^{b}$ & 103.7 & 53.8 & 110.2 & 315 (4.10) & $322(4.16)$ & 690 \\
\hline $\mathrm{N}\left(\mathrm{C}_{2} \mathrm{H}_{4}\right)_{3} \mathrm{CH}, 3 \mathrm{c}$ & 2032 & -6.0 & $4.70,3.61$ & 3.02 & $146.1(14.4)^{d}$ & 103.1 & n. det. & 107.2 & 311 (3.88) & $320(3.91)$ & 900 \\
\hline $\operatorname{EtN}\left(\mathrm{CH}_{2}\right)_{4} \mathrm{O}, \mathbf{3 d}$ & 2027 & -6.2 & $4.65,3.96$ & 2.93 & $146.9(14.8)^{c}$ & 100.0 (1.6) & 58.9 & 112.5 & 314 (3.96) & 320 (3.97) & 600 \\
\hline $\mathrm{Me}_{3} \mathrm{acn}, \mathbf{3 e}$ & 2037 & -6.3 & $4.69,3.84$ & 2.83 & $144.7(14.5)^{\mathrm{b}}$ & 99.6 & 57.9 & 108.2 & $310(3.732)$ & 317 (3.699) & 740 \\
\hline $\mathrm{PhCH}_{2} \mathrm{NMe}_{2}, \mathbf{3 f}$ & 2033 & -5.9 & $4.39,3.66$ & 3.09 & $146.6(14.6)^{c}$ & $100.8(1.2)$ & 55.3 & 109.3 & 316 (4.11) & $321(3.92)$ & 490 \\
\hline $\begin{array}{c}\text { 3-OMePhCH} 2^{-} \\
\mathrm{NMe}_{2}, \mathbf{3 g}\end{array}$ & 2032 & $-5.9 c$ & $4.45,3.75$ & 3.05 & $147.1(14.5)^{c}$ & $100.9(1.2)$ & 55.4 & 109.1 & $313(4.01)$ & $319(4.01)$ & 570 \\
\hline 4-DMAP, $3 \mathbf{h}$ & 2051 & -6.6 & $4.85,3.96$ & 1.50 & $145.2(14.7)^{d}$ & $103.4(1.6)$ & n. det. & 105.1 & 308 (4.39) & $308(4.49)$ & 0 \\
\hline
\end{tabular}

a As $\mathrm{KBr}$ pellet. b Spectra recorded in $\mathrm{CDCl}_{3}$. ${ }^{\mathrm{c}}$ Spectra recorded in $\mathrm{CD}_{3} \mathrm{CN}$. d Spectra recorded in $\mathrm{CD}_{2} \mathrm{Cl}_{2}$.

ent reactivity of some of the amines with the solvent $\mathrm{CH}_{2} \mathrm{Cl}_{2} \cdot{ }^{31,32}$ In cases where chloromethylation was expected to be a major problem, chlorobenzene had to be used with the drawback of Ionger reaction times (see Experimental Section).

The outcome of the amine trapping of butatrienylidene intermediates $\mathbf{2}$ is in remarkable contrast to observations in the $\mathrm{RuCl}_{2}(\mathrm{dppm})_{2} /$ acetylene/amine and the $\mathrm{RuCl}_{2}(\mathrm{dppe})_{2} /$ phenyl butadiyne/NE $t_{3}$ systems, where the amine strictly acts as a base and not as a nucleophile. $26 c, d, 28$ In no case, not even in the presence of the only weakly nucleophilic and strongly basic DBU, did we observe a similar conversion of the proposed butatrienylidene intermediate $\mathbf{2}$ into a diynyl complex. As one may reasonably expect the acidities of a coordinated vinylidene and butatrienylidene to be rather similar, one may ascribe this different behavior to the steric protection of $\mathrm{C}_{\alpha}$ by bulky phosphine substituents combined with the relative hardness of amine nucleophiles. ${ }^{33}$ The el ectrophilic $\mathrm{C}_{\gamma}$ is sufficiently remote from the metal center to all ow for amine addition, even more so when, as in our case, no bulky substituents are attached to $\mathrm{C}_{\delta}$. This latter thought finds support from the fact that the phenylbutadiyne-derived dppe analogue of $\mathbf{2}$ is deprotonated to the diynyl complex trans$\left[\mathrm{Cl}(\text { dppe })_{2} \mathrm{Ru}-\mathrm{C} \equiv \mathrm{C}-\mathrm{C} \equiv \mathrm{C}-\mathrm{Ph}\right] .{ }^{28}$ Previous investigations have clearly revealed that the addition of basic nucleophiles to allenylidene complexes may result in addition to either $\mathrm{C}_{\alpha}$ or $\mathrm{C}_{\gamma}$ depending on steric and electronic properties of the nucleophilic reagent, the metal fragment, and the unsaturated ligand. $2 \mathrm{~b}, \mathrm{e}, 3 \mathrm{~b}, 7-10$ In the case of rather basic, electron-rich $\mathrm{Ru}(\mathrm{II})$ fragments hard nucleophiles were found to preferentially attack $\mathrm{C}_{\gamma}$, while soft nucleophiles tend to add to

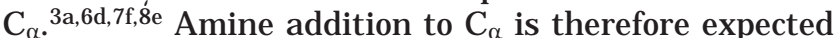
to be an unfavorable process from both steric and electronic arguments. This leads to deprotonation rather

(31) (a) Mills, J . E.; Maryanoff, C. A.; Cosgrove, R. M.; Scott, L.; McComsey D. F. Org. Prep. Proc. Int. 1984, 16, 97. (b) Nevstad G. O. Songstad, J . Acta Chem. Scand. Ser. B 1984, 38, 469.

(32) Winter, R. F.; Wolmershäuser, G. J . Organomet. Chem. 1998 $570,201$.

(33) A reviewer pointed out that the concomitant formation of ruthenium amine complexes cis-[RuCl$\left.\left(\mathrm{NR}_{2} \mathrm{R}^{\prime}\right)(\mathrm{dppm})_{2}\right]^{+}$argues against any steric impediment toward amine addition to the $\alpha$-carbon of intermediate 2. Simple ball-and-stick models, however, show that the presence of a branched chain resulting from addition to $\mathrm{C}_{\alpha}$ induces much higher congestion than amine ligation to a cis- $\left\{\mathrm{CIRu}(\mathrm{dppm})_{2}\right\}^{+}$ fragment. According to such models free rotation of the amine is possible in amine derivatives 4 , while this is definitely not the case in hypothetical trans- $\left[\mathrm{Cl}(\mathrm{dppm})_{2} \mathrm{Ru}-\mathrm{C}\left(\mathrm{NR}_{2} \mathrm{R}^{\prime}\right)^{+}=\mathrm{C}=\mathrm{C}=\mathrm{CH}_{2}\right]^{+}$. We note however, that amine coordination to the unsaturated intermediate fac,cis-[(PNP)RuCl - CCPh] (PNP $\left.=\mathrm{C}_{3} \mathrm{H}_{7} \mathrm{~N}\left(\mathrm{C}_{2} \mathrm{H}_{4} \mathrm{PPh}_{2}\right)_{2}\right)$ failed for more bulky secondary or tertiary amines, which was ascribed to sterical hindrance. ${ }^{34}$ than addition in the vinylidene complexes and to the observed regiosel ectivity in our butatrienylidene intermediate 2

Compounds $\mathbf{3}$ are only moderately sensitive to moisture or air, dissolve well in $\mathrm{CH}_{2} \mathrm{Cl}_{2}$ and $\mathrm{CH}_{3} \mathrm{CN}$ and moderately in $\mathrm{CHCl}_{3}, \mathrm{PhCl}$, and 1,4-dioxane, and are practically insoluble in hydrocarbons and ether. The colors of their solutions range from bluish green for saturated amine derivatives $\mathbf{3 a}-\mathbf{3 e}$ to pal e ol ive green for the benzylic derivatives $\mathbf{3 f}, \mathbf{g}$ and dark orange for the pyridine derivative $\mathbf{3 h}$. The 2 -ammoniobutenynyl complexes $\mathbf{3}$ are easily identified by their characteristic spectroscopic properties as collected in Table 1 . The unsaturated ligand of $\mathbf{3}$ leads to a sharp absorption of medium intensity at 2037-2031 wavenumbers in the IR with the exception of the pyridine-derived ligand in $3 \mathbf{h}$, where this absorption is shifted to $2051 \mathrm{~cm}^{-1}$. The trans dispositions of the chlorine and the unsaturated ligand are confirmed by the presence of just one sharp singlet in the ${ }^{31 P}$ NMR spectra centered in a narrow region around $-6 \mathrm{ppm}$. The most characteristic features in the ${ }^{1} \mathrm{H} N M R$ spectra are two doublets of quintets for the methylene groups of the dppm ligands and the two different absorptions of the terminal vinyl protons. These signals appear rather high field shifted at 3.6$4.9 \mathrm{ppm}$ and thus in a similar region as in 1-alkoxyvinyltrimethylammonium salts, 35 consistent with the good donor ability of the trans-[CIRu(dppm)- $C \equiv C$ ] substituent. In most cases one of these signals is rather broad while the other appears as a sharp doublet with a characteristic small geminal coupling of $1.5-3.1 \mathrm{~Hz}$. All four carbon atoms of the unsaturated ligand are identified in the ${ }^{13} \mathrm{C}$ NMR spectra. The resonance signal of the $\alpha-C$ atom is split into a quintet arising from coupling to the four equivalent phosphorus nuclei at the neighboring Ru center and appears at ca. 146 ppm. $C_{\delta}$ is easily identified by DE PT experiments and resonates as a sharp singlet at ca. $110 \mathrm{ppm} . \mathrm{C}_{\beta}$ and $\mathrm{C}_{\gamma}$, on the other hand, give weaker and broad resonance signals resulting from coupling to either the $\mathrm{P}$ atoms or nitrogen. We assign the signal at 100-104 ppm to $\mathrm{C}_{\beta}$ and the signal at 54-59 ppm to $C_{\gamma}$ for the following reasons. For some complexes $\mathbf{3}$ a quintet coupling of about $1-2 \mathrm{~Hz}$ was clearly resolved for the signal at 100 ppm. Similar chemical shift values and couplings were reported for $\mathrm{C}_{\beta}$ in other Ru-enynyl complexes. 2e,3a,7d,10c,36 The unusual high-field shift of $\mathrm{C}_{\gamma}$ on the other hand has no precedent in Ru-enynyl complexes. In a 2-phospho-

(34) Bianchini, C.; Masi, D.; Romerosa, A.; Zanobini, F.; Peruzzini, M. Organometallics 1999, 18, 2376.

(35) Herkes, F. E.; Simmons, H. E. J . Org. Chem. 1973, 38, 2845. 
niobutenynyl complex closely related to $\mathbf{3}$ the signal of $\mathrm{C}_{\gamma}$ was unambiguously assigned by virtue of the $\mathrm{P}-\mathrm{C}$ coupling and located at much lower field at $117 \mathrm{ppm} .{ }^{24 \mathrm{c}}$ The ${ }^{1} \mathrm{H}$ signals of the respective amine substituents integrate in a 1:1 ratio relative to the metal fragment and the $\mathrm{C}_{4} \mathrm{H}_{2}$ unit. Both ${ }^{1} \mathrm{H}$ and ${ }^{13} \mathrm{C}$ resonances are, on average, slightly shifted upfield from the respective free amine in accordance with the formation of quaternary ammonium salts. For $\mathbf{3 h}$ the ${ }^{1 \mathrm{H}} \mathrm{NMR}$ and ${ }^{13} \mathrm{C}$ NMR shifts of the substituted pyridine are almost identical to those of the (4-dimethylamino)methylpyridinium cation where the methyl group is attached to the pyridine nitrogen. ${ }^{37}$ This lets us propose the same regiochemistry for $\mathbf{3 h}$. In no case, however, did we detect a coupling of one of the carbons attached to nitrogen to the ${ }^{14} \mathrm{~N}$ nucleus. Such splittings are frequently observed for more symmetrical organic ${ }^{38}$ or organometallic ${ }^{32}$ ammonium ions. UV/Vis investigations identify the bluegreen color of compounds $\mathbf{3}$ as arising from a rather weak $(\epsilon<600)$ band in the $630-640 \mathrm{~nm}$ region. In some cases, additional features in the visible region are also present, mostly as shoulders. Besides the highly intense $\mathrm{n}-\pi^{*}$ and $\pi-\pi^{*}$ transitions arising from the arene phosphine substituents ${ }^{39}$ they exhibit another intense band $\left(\epsilon \mathrm{ca} .10^{4}\right)$ at ca. $315-320 \mathrm{~nm}$ that may be ascribed to a $\pi-\pi^{*}$ transition within the unsaturated ligand. This band is probably associated with some charge transfer from the electron-rich metal fragment to the electronwithdrawing alkynyl system (MLCT), as indicated by a negative solvatochroism with $\Delta v$ ranging from 500 to $900 \mathrm{~cm}^{-1}$ between $\mathrm{CH}_{2} \mathrm{Cl}_{2}$ and $\mathrm{CH}_{3} \mathrm{CN}$ solutions. A similar band in an essentially identical region has also been observed in cyanide-bridged dirhenium complexes with the same $d^{6}$ electron configuration where one of the termini acts as a Lewis acid and the other one as a Lewis base. 40

The solid-state structure of trans-[CIRu(dppm $)_{2}-\mathrm{C} \equiv$ $\left.\mathrm{C}-\mathrm{C}\left(\mathrm{NEt}_{3}\right)=\mathrm{CH}_{2}\right]^{+} \mathrm{PF}_{6}-$ has already been communicated. ${ }^{25 a} \mathrm{~A}$ plot of the cation is shown in Figure 1 , and the more rel evant bond lengths and angl es are provided in Table 2. Details of the structure determination are outlined in Table 3 . The conjugated $\mathrm{C}_{4} \mathrm{~N}$ ligand is essentially planar and coplanar with the metal and the $\mathrm{Cl}^{-}$ligand trans to it. This plane is al most perpendicular to the best plane $\mathrm{RuP}_{4}$ (interplanar angle $87.3(4)^{\circ}$ ). Unfortunately the quality of this structure is rather low and does not allow for a detailed discussion of the $\mathrm{Ru}-\mathrm{C}$ and individual $\mathrm{C}-\mathrm{C}$ bond lengths. Nevertheless the proposed structure and bonding scheme are fully confirmed. The $\mathrm{Ru}-\mathrm{Cl}$ distance $(2.02(2) \AA)$ is in good agreement with data found for other cationic $\mathrm{Ru}(\mathrm{II})$ alkynyl complexes, e.g., trans-[( $\left.\left.\mathrm{H}_{2}\right) \mathrm{Ru}(\text { dippe })_{2}-\mathrm{CCPh}\right)^{+}$ (2.01(1) $\AA),{ }^{41}\left[\mathrm{Cp} * \mathrm{RuH} \text { (dippe) } \mathrm{C} \equiv \mathrm{CCO}_{2} \mathrm{Me}\right]^{+}(2.04(2) \AA),{ }^{42}$

(36) Cadierno, V.; Conejero, S.; Gamasa, M. P.; Gimeno, J .; Asselberghs, I.; Houbrechts, S.; Clays, K.; Persoons, A.; Borge, J .; GarcíaGranda, S. Organometallics 1999, 18, 582.

(37) Hünig, S.; Ort, B.; Wenner, H. Liebigs Ann. Chem. 1985, 751.

(38) Coddington, J. M.; Taylor, M. J . Spectrochim. Acta 1990, 46a, 1487.

(39) (a) Fife, D. J .; Morse, K. W.; Moore, W. M. J . Photochem. 1984, 24, 249. (b) Goetz, H.; Nerdel, F.; Wiechel, K.-H. Liebigs Ann. Chem. 1963, 665, 1.

(40) Stark. G. A.; Arif, A. M.; Gladysz, J . A. Organometallics 1997, 16, 2809.

(41) J iménez-Tenorio M.; Puerta, M. C.; Valerga, P. J . Chem. Soc., Chem. Commun. 1997, 1750.

(42) de los Ríos, I.; J iménez-Tenorio M.; Puerta, M. C.; Valerga, P. J. Am. Chem. Soc. 1997, 119, 6529.

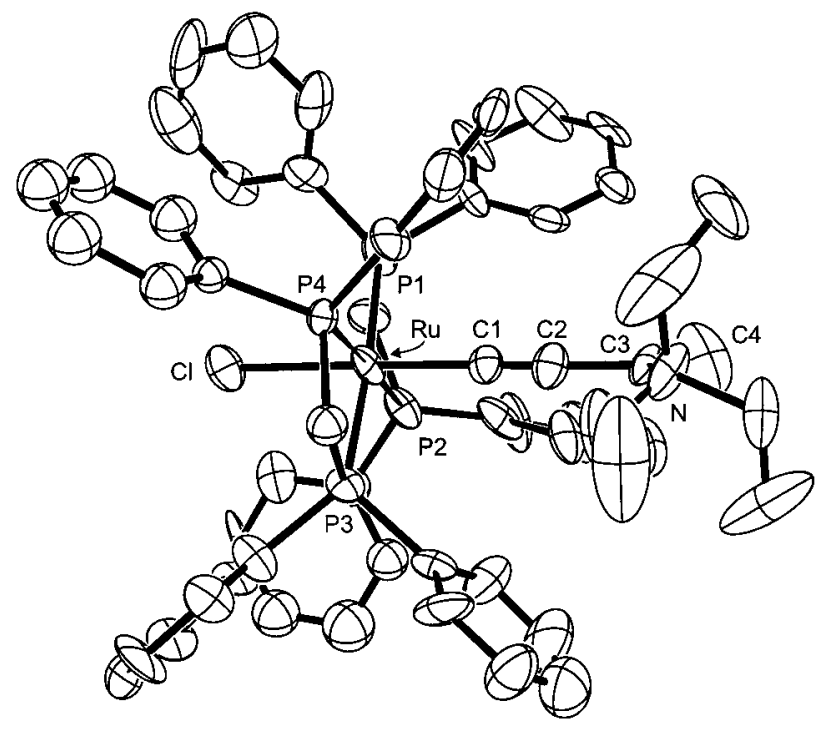

Figure 1. Plot of the cation trans- $\left[\mathrm{Cl}(\mathrm{dppm})_{2} \mathrm{Ru}-\mathrm{C} \equiv \mathrm{C}-\right.$ $\left.\mathrm{C}\left(\mathrm{NEt}_{3}\right)=\mathrm{CH}_{2}\right]^{+}$of compound 3 a with the atomic labeling scheme of the more important atoms. Hydrogen atoms have been omitted for clarity.

\begin{tabular}{|c|c|c|c|}
\hline $\begin{array}{l}\mathrm{Ru}-\mathrm{C}(1) \\
\mathrm{Ru}-\mathrm{P}(1) \\
\mathrm{Ru}-\mathrm{P}(2) \\
\mathrm{Ru}-\mathrm{P}(3) \\
\mathrm{Ru}-\mathrm{P}(4) \\
\mathrm{Ru}-\mathrm{Cl}\end{array}$ & $\begin{array}{l}2.02(2) \\
2.383(5) \\
2.373(5) \\
2.337(5) \\
2.310(5) \\
2.460(5)\end{array}$ & $\begin{array}{l}C(1)-C(2) \\
C(2)-C(3) \\
C(3)-C(4) \\
C(3)-N \\
N-C(511) \\
N-C(521) \\
N-C(531)\end{array}$ & $\begin{array}{l}1.12(2) \\
1.51(2) \\
1.34(3) \\
1.47(2) \\
1.48(3) \\
1.54(3) \\
1.52(2)\end{array}$ \\
\hline $\begin{array}{l}\mathrm{P}(2)-\mathrm{Ru}-\mathrm{P}(1) \\
\mathrm{P}(3)-\mathrm{Ru}-\mathrm{P}(1) \\
\mathrm{P}(4)-\mathrm{Ru}-\mathrm{P}(1) \\
\mathrm{P}(3)-\mathrm{Ru}-\mathrm{P}(2) \\
\mathrm{P}(4)-\mathrm{Ru}-\mathrm{P}(2) \\
\mathrm{P}(4)-\mathrm{Ru}-\mathrm{P}(3) \\
\mathrm{P}(1)-\mathrm{Ru}-\mathrm{Cl} \\
\mathrm{P}(2)-\mathrm{Ru}-\mathrm{Cl} \\
\mathrm{P}(3)-\mathrm{Ru}-\mathrm{Cl} \\
\mathrm{P}(4)-\mathrm{Ru}-\mathrm{Cl}\end{array}$ & $\begin{array}{r}69.8(2) \\
175.4(2) \\
109.1(2) \\
109.0(2) \\
176.6(2) \\
71.8(2) \\
83.3(2) \\
85.0(2) \\
92.2(2) \\
91.7(2)\end{array}$ & $\begin{array}{l}\mathrm{C}(1)-\mathrm{Ru}-\mathrm{P}(1) \\
\mathrm{C}(1)-\mathrm{Ru}-\mathrm{P}(2) \\
\mathrm{C}(1)-\mathrm{Ru}-\mathrm{P}(3) \\
\mathrm{C}(1)-\mathrm{Ru}-\mathrm{P}(4) \\
\mathrm{C}(1)-\mathrm{Ru}-\mathrm{Cl} \\
\mathrm{C}(2)-\mathrm{C}(1)-\mathrm{Ru} \\
\mathrm{C}(1)-\mathrm{C}(2)-\mathrm{C}(3) \\
\mathrm{C}(4)-\mathrm{C}(3)-\mathrm{N} \\
\mathrm{C}(4)-\mathrm{C}(3)-\mathrm{C}(2) \\
\mathrm{C}(2)-\mathrm{C}(3)-\mathrm{N}\end{array}$ & $\begin{array}{l}99.6(5) \\
98.1(5) \\
84.9(5) \\
85.3(5) \\
176.3(5) \\
175(2) \\
167(2) \\
123(2) \\
124(2) \\
113(2)\end{array}$ \\
\hline
\end{tabular}

and trans-[( $\left.\left.\left.\mathrm{NH}_{3}\right) \mathrm{Ru}(\text { dppe })_{2}-\mathrm{CCPh}\right)\right]^{+}(2.014(5) \AA),{ }^{43}$ but somewhat longer as in the acceptor-substituted neutral enynyl complex $\left[\left(\eta^{5}-\mathrm{C}_{9} \mathrm{H}_{7}\right) \mathrm{Ru}\left(\mathrm{PPh}_{3}\right)_{2}-\mathrm{C} \equiv \mathrm{C}-\mathrm{CH}=\mathrm{C}\left(\mathrm{C}_{6} \mathrm{H}_{4-}\right.\right.$ $\left.\mathrm{NO}_{2}-3\right)_{2}$ ] (1.97(1) $\AA$ ). ${ }^{36}$ The $\mathrm{C} 1-\mathrm{C} 2$ and $\mathrm{C} 2-\mathrm{C} 3$ distances in $3 \mathbf{a}$ are probably artificially short (1.12(2) $\AA$ ) and long $(1.51(2) \AA)$, respectively, especially if compared with [ $\left(\eta^{5}-\right.$ $\left.\left.\mathrm{C}_{9} \mathrm{H}_{7}\right) \mathrm{Ru}\left(\mathrm{PPh}_{3}\right)_{2}-\mathrm{C} \equiv \mathrm{C}-\mathrm{CH}=\mathrm{C}\left(\mathrm{C}_{6} \mathrm{H}_{4} \mathrm{NO}_{2}-3\right)_{2}\right]$, where values of $1.23(2)$ and $1.42(2) \AA$ have been found. ${ }^{36}$ The $C 3-$ C4 distance of 1.34(3) $\AA$ is unexceptional, as are the $\mathrm{Ru}-\mathrm{P}$ and $\mathrm{Ru}-\mathrm{Cl}$ bond lengths. The $\mathrm{N}-$ vinyl $\mathrm{C}$ bond of $1.46(2) \AA$ appears to be slightly shorter than the remaining $\mathrm{N}-\mathrm{C}$ bond lengths $(1.50(2)-1.52(3) \AA)$. The angles $\mathrm{Cl}-\mathrm{Ru}-\mathrm{C} 1\left(176.3(5)^{\circ}\right), \mathrm{Ru}-\mathrm{C} 1-\mathrm{C} 2\left(175(2)^{\circ}\right)$, and $\mathrm{C} 1-\mathrm{C} 2-\mathrm{C} 3\left(167(2)^{\circ}\right)$ are close to linear, while the C2C3-C4 angle of $124(2)^{\circ}$ corresponds to an $\mathrm{sp}^{2}$ hybridized carbon, as does the angle sum of $360^{\circ}$ at C3.

Electrochemical and in Situ Spectroelectrochemical Investigations of $\mathbf{3} \mathbf{a}-\mathbf{h}$. Complexes $\mathbf{3} \mathbf{a}-\mathbf{h}$ are electroactive and were investigated by means of cyclic and square wave voltammetry in various sol vents

(43) Touchard, D.; Haquette, P.; Guesmi, S.; Le Pichon, L.; Daridor A.; Toupet, L. Dixneuf, P. H. Organometallics 1997, 16, 3640. 
Table 3. Crystallographic Data for Complex 3a

\begin{tabular}{ll}
\hline formula & $\mathrm{C}_{60} \mathrm{H}_{61} \mathrm{NClF}_{6} \mathrm{P}_{5} \mathrm{Ru}$ \\
fw & 1202.48 \\
temperature & $183(2) \mathrm{K}$ \\
wavelength & $0.71073 \AA$ \\
crystal system & monoclinic \\
space group & $\mathrm{P} 2(1) / \mathrm{n}$ \\
a & $13.167(3) \AA$ \\
$\mathrm{b}$ & $21.127(4) \AA$ \\
$\mathrm{C}$ & $20.644(4) \AA$ \\
$\beta$ & $96.94(3)^{\circ}$ \\
$\mathrm{V}$ & $5701(2) \AA^{3}$ \\
$\mathrm{Z}$ & 4 \\
density (calcd) & $1.401 \mathrm{Mg} / \mathrm{m}^{3}$ \\
absorption coeff & $0.521 \mathrm{~mm}{ }^{-1}$ \\
$\mathrm{~F}(000)$ & 2476 \\
crystal size & $0.35 \times 0.25 \times 0.2 \mathrm{~mm}$ \\
$\theta$ range for data collection & $1.74-23.00^{\circ}$ \\
index ranges for data & $-15 \leq \mathrm{h} \leq 15,-13 \leq \mathrm{k} \leq 25$, \\
$\quad$ collection & $-24 \leq \mathrm{I} \leq 24$ \\
no. of reflns msd & 9685 \\
no. of indep reflns & $7910[\mathrm{R}(\mathrm{int})=0.0514]$ \\
refinement method & full-matrix least-squares on $\mathrm{F}^{2}$ \\
data/restraints/params & $7698 / 0 / 608$ \\
goodness-of-fit on $\mathrm{F}^{2}$ & 3.932 \\
final $\mathrm{R}$ indices [I $>$ 2 $\sigma(\mathrm{I})]$ & $\mathrm{R} 1=0.1832$, wR2 $=0.3055$ \\
$\mathrm{R}$ indices (all data) & $\mathrm{R} 1=0.2092$, wR2 $=0.4194$ \\
largest diff peak and hole & 1.508 and $-2.199 \mathrm{e} \AA^{-3}$ \\
&
\end{tabular}

Table 4. Electrochemistry Data for Complexes 3a-3h

\begin{tabular}{|c|c|c|c|}
\hline compound & solvent & $\mathrm{E}_{1 / 2} \mathrm{Ox}[\mathrm{V}]\left(\Delta \mathrm{E}_{\mathrm{p}}\right)[\mathrm{mV}]^{\mathrm{a}}$ & $E_{p}^{\text {red, b }}$ \\
\hline $3 a$ & $\begin{array}{l}\text { THF } \\
\mathrm{CH}_{2} \mathrm{Cl}_{2}\end{array}$ & $\begin{array}{l}+0.275(66) \\
+0.330(66)\end{array}$ & $-2.71,-2.86$ \\
\hline $3 b$ & $\mathrm{CH}_{2} \mathrm{Cl}_{2}$ & $+0.255(65)$ & \\
\hline 30 & $\begin{array}{l}\text { THF } \\
\text { DMF } \\
\mathrm{CH}_{3} \mathrm{CN}\end{array}$ & $\begin{array}{l}+0.240(64) \\
+0.290(68) \\
+0.330(62)\end{array}$ & $\begin{array}{l}-2.71,-2.88 \\
-2.61,-2.84\end{array}$ \\
\hline 3d & $\begin{array}{l}\text { THF } \\
\text { DCE }\end{array}$ & $\begin{array}{l}+0.300(81) \\
+0.355(63)\end{array}$ & $-2.69,-2.87$ \\
\hline $3 f$ & $\begin{array}{l}\mathrm{CH}_{3} \mathrm{CN} \\
\mathrm{THF} \\
\mathrm{CH}_{2} \mathrm{Cl}_{2} \\
\mathrm{CH}_{3} \mathrm{CN}\end{array}$ & $\begin{array}{l}+0.375(64) \\
+0.295(64) \\
+0.360(63) \\
+0.370(63)\end{array}$ & $\begin{array}{l}-2.58,-2.66 \\
-2.66,-2.76\end{array}$ \\
\hline $3 g$ & $\begin{array}{l}\mathrm{THF} \\
\mathrm{DMF} \\
\mathrm{CH}_{3} \mathrm{CN}\end{array}$ & $\begin{array}{l}+0.300(73) \\
+0.315(73) \\
+0.365(61)\end{array}$ & $\begin{array}{l}-2.69,-2.90 \\
-2.58,-2.71\end{array}$ \\
\hline $3 h$ & $\begin{array}{l}\text { THF } \\
\text { DCE } \\
\mathrm{CH}_{3} \mathrm{CN}\end{array}$ & $\begin{array}{l}+0.200^{d} \\
+0.240(62) \\
+0.270(59)\end{array}$ & $\begin{array}{l}-2.28 \\
-2.25 \\
-2.17\end{array}$ \\
\hline
\end{tabular}

a $E_{1 / 2}$ as calibrated vs the internal ferrocene/ferrocenium standard, $\Delta \mathrm{E}_{\mathrm{p}}$ corrected for ohmic drop by comparison with the internal standard at $\mathrm{v}=1 \mathrm{~V} / \mathrm{s}$. ${ }^{\mathrm{b}}$ Peak potentials of irreversible processes at $\mathrm{v}=0.2 \mathrm{~V} / \mathrm{s}$. ${ }^{\mathrm{c}}$ At $232 \mathrm{~K} .{ }^{\mathrm{d}}$ Not completely reversible.

(THF, DMF, $\mathrm{CH}_{3} \mathrm{CN}, \mathrm{CH}_{2} \mathrm{Cl}_{2}$, or $1,2-\mathrm{Cl}_{2} \mathrm{C}_{2} \mathrm{H}_{4}$ (DCE)) and on $\mathrm{Pt}$ and glassy carbon electrodes. Most of them undergo a well-behaved one-electron oxidation at potentials that are independent of the electrode material and range from +0.255 to $+0.365 \mathrm{~V}\left(\mathrm{CH}_{2} \mathrm{Cl}_{2}\right)$ versus the ferrocene/ferrocenium standard depending on the amine substituent. Exceptions are compounds $\mathbf{3 b}, \mathbf{3 e}$, and $\mathbf{3 h}$. For $\mathbf{3 b} \mathbf{b}, \mathbf{h}$ higher sweep rates and/or low temperatures were required to allow for observation of the associated cathodic peak, while the oxidation wave of $3 \mathbf{e}$ was al together irreversible. All pertinent data are collected in Table 4.

At higher sweep rates the oxidation waves were frequently slightly broadened with respect to the ferrocene standard. This is attributed to somewhat slow el ectron-transfer kinetics. In all instances the forward wave was more affected than the reverse wave, thus pointing to a value of (1- $\alpha$ ) smaller than $0.5 .{ }^{44}$ From the wave broadening the electron-transfer rate constants $k_{s}$ and electron-transfer coefficients $\alpha$ were estimated ${ }^{45}$ and further refined by digital simulation (see Experimental Section for details). $\mathrm{k}_{\mathrm{s}}$ and $\alpha$ values thus obtained are on the order of about $0.15 \mathrm{~cm} / \mathrm{s}$ and 0.6 , respectively. Similar behavior has been encountered on various occations for Ru-based redox centers. To obtain a reliable estimate for $k_{s}$ the diffusion coefficients of $3 c$ and $\mathbf{3 h}$ were determined by chronoamperometry at 296 $\mathrm{K}\left(3 \mathrm{c}, 1.35 \mathrm{mM}\right.$ with $0.3 \mathrm{M} \mathrm{NBu}_{4} \mathrm{PF}_{6}$ in $\mathrm{THF}, \mathrm{D}=0.29$ $\times 10^{-5} \mathrm{~cm}^{2} \mathrm{~s}^{-1}$; $3 \mathrm{~h}, 2.45 \mathrm{mM}$ with $0.6 \mathrm{M} \mathrm{NBu}_{4} \mathrm{PF}_{6}$ in DCE, $\left.D=0.14 \times 10^{-5} \mathrm{~cm}^{2} \mathrm{~s}^{-1}\right)$.

We will specify below that the SOMO of the resulting oxidation product has appreciable metal character. The oxidation is thus best described as arising from a Ru(II/III) couple. There is a general trend that the more basic and thus electron-rich amines lead to lower oxi dation potentials. From the above reasoning this can be rationalized in terms of a higher el ectron density at the otherwise identical metal fragment as the $\{-C \equiv$ $\left.\mathrm{C}-\mathrm{C}\left(\mathrm{NR}_{3}\right)=\mathrm{CH}_{2}\right\}^{+}$ligand becomes a less potent el ectron acceptor. This provides evidence that the conjugated $C_{3}$ ligand effectively transmits charge between the ammonium and metal termini. The oxidation potentials of each derivative of $\mathbf{3}$ were also found to be solvent dependent (see Table 4). Changing the solvent from THF to $\mathrm{CH}_{3} \mathrm{CN}$ causes an anodic shift of some 70-90 $\mathrm{mV}$. This may be attributed to the preferential stabilization of a charged species with respect to neutral ferrocene as the polarity of the solvent increases.

In addition to the well-behaved oxidation, complexes 3 also undergo more complicated, ill-defined, and chemically irreversible reductions at fairly negative potentials. In most instances this process could only be observed in either THF or DMF but was outside the solvent limits of $\mathrm{CH}_{3} \mathrm{CN}$ or $\mathrm{CH}_{2} \mathrm{Cl}_{2}$. Never did we observe an associated anodic return peak such that the potentials in Table 4 refer to the peak position of an irreversible feature at a sweep rate of $0.2 \mathrm{~V} / \mathrm{s} .{ }^{46}$ The overall reduction of complexes $\mathbf{3 a - g}$ occurs in two separate, closely spaced waves. Due to the close proximity of the waves to the cathodic limit of the electrolyte solution and their considerable breadth, we can, however, provide no definitive answer about the exact number of electrons associated with each of these waves. The only exception is the pyridine-derived complex $\mathbf{3 h}$, where a single irreversible one-el ectron wave appears at considerably less cathodic potentials. Similar behavi or was observed for the reduction of the 4-(dimethylamino)methyl pyridinium ion, ${ }^{37}$ and this provides more evidence for the binding via the pyridine rather than the amine nitrogen in $\mathbf{3 h}$.

We investigated the overall reduction process in some detail for the quinuclidine complex $\mathbf{3 c}$ and note that qualitative identical behavior was observed for other complexes $3 \mathbf{3}-\mathbf{g}$. Following reduction several new electroactive species are observed, the most prominent being

(44) The dimensionless parameter $\alpha$ provides a measure for the symmetry of the transition state for the electron-transfer reaction and usually has values between 0.3 and 0.7 .

(45) Nicholson, R. S. Anal. Chem. 1965, 37, 1351.

(46) N ote that for an irreversible wave the peak position depends on the sweep rate $v$ and, at room temperature, shifts to more extreme potentials by $30 / \mathrm{n} \mathrm{mV}$ for each 10 -fold increase in $\mathrm{v}$. 
an irreversible reduction wave at $E_{p}=-0.78 \mathrm{~V}$. If the overall sweep is initiated in cathodic direction past the reduction waves and then continued to positive of the $\mathrm{Ru}(\mathrm{II} / \mathrm{II}$ ) couple, a severe loss of reversibility along with a slight cathodic displacement of the oxidation wave of 3c are observed. In addition a new wave appears at about $+0.56 \mathrm{~V}, 0.27 \mathrm{~V}$ positive of the oxidation wave of 3c. This is shown in Figures $2 b$ and $3 b$ for cyclic voltammetry and square wave traces. All these features are absent if the oxidation is scanned first (or if the sweep is initiated positive of the Ru(II/III) couple; see Figures $2 \mathrm{a}$ and $3 a$ ). Complexes $\mathbf{3}$ may be envisaged as organometallic quaternary ammonium salts. Unsymmetric ammonium ions $N R_{3} R^{\prime}$ are known to be selectively cleaved upon reduction according to eq 1 , preferentially releasing the most stable radical species. ${ }^{47}$

$$
\mathrm{NR}_{3} \mathrm{R}^{\prime+}+\mathrm{e}^{-} \rightarrow \mathrm{NR}_{3}+\mathrm{R}^{\prime}
$$

Thus, one may expect that the free amine initially employed in the trapping of our Ru-butatrienylidene intermediate $\mathbf{2}$ is released during the overall reduction. We therefore recorded CV and square wave traces of 3c after adding incrementally increasing amounts of quinuclidine. These experiments were performed in the presence of ferrocene as an internal standard for potential calibration since added amine was found to shift the experimental potential scale of the $\mathrm{Ag}^{0 /+}$ pseudo-reference electrode. Amine addition had exactly the same effect on the anodic behavior of $\mathbf{3 c}$ as initiating the sweep in (or from) the cathodic direction. This is illustrated in Figures $2 \mathrm{c}$ and $3 \mathrm{c}$, which depict traces in the presence of 1.2 equiv of added amine. We therefore conclude that the overall reduction releases the free amine and that the Ru(III) oxidation product is reactive toward this amine. This may also account for the completely irreversible oxidation of the triazacydononanederived complex 3e, where free amine sites are present within the cation itself.

Spectroelectrochemical Investigations. Since several of the oxidation products of $\mathbf{3}$ possess considerable chemical stability, we sought to investigate these species by means of EPR, UV/Vis, and IR spectroelectrochemistry. At $110 \mathrm{~K}$ electrochemically oxidized samples of 3a and $\mathbf{3 f}$ exhibit rhombic patterns with considerable anisotropy of the individual g-values and average gvalues significantly deviating from that of the free electron $\left(3 \mathrm{a}, \mathrm{g}_{\mathrm{x}}=2.3815, \mathrm{~g}_{\mathrm{y}}=2.1547, \mathrm{~g}_{\mathrm{z}}=1.9381\right.$, $\mathrm{g}_{\mathrm{av}}$ $=2.158$; 3e, $g_{x}=2.4057, g_{y}=2.1598, g_{z}=1.9376, g_{a v}=$ 2.168). No signals are observed in fluid solution. In light of these results we conclude that in the oxidized product the unpaired spin resides in an orbital with considerable metal character and that the oxidation may thus be assigned as a $\mathrm{Ru}(\mathrm{II} / \mathrm{III})$ couple.

The results of in situ UV/vis spectroelectrochemistry of $\mathbf{3 e}$ are shown in Figure 4 . U pon oxidation of $\mathbf{3 e}$, the strong band near $310 \mathrm{~nm}$ is gradually replaced by a new feature at higher energy. It appears at ca. $280 \mathrm{~nm}$ as a shoulder on the low-energy part of the $n-\pi^{*}$ band of the dppm ligands. Weaker bands are observed in the visible region at 373 and $327 \mathrm{~nm}$. The results of IR spectroel ectrochemistry were rather disappointing. Here

(47) Dubois, J . E.; Monvernay, A.; Lacaze, P. C. Electrochim. Acta 1970, 15, 315.

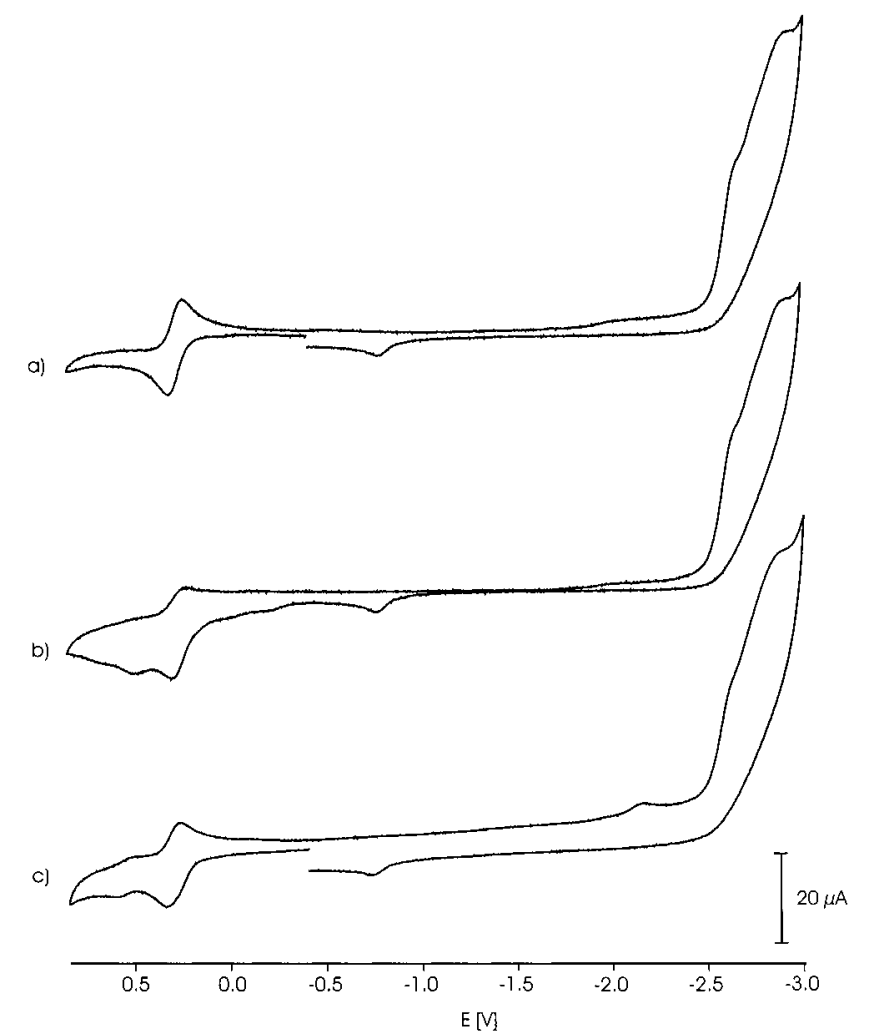

Figure 2. CV traces of the quinuclidine derivative $\mathbf{3 c}$ in DMF : (a) anodic scan first; (b) cathodic scan first; (c) after addition of 1.2 equiv of free quinclidine, anodic scan first.

the $\mathrm{C} \equiv \mathrm{C}$ stretch of the starting compound simply vanishes upon oxidation, and no new band was found in the region between 2200 and 1500 wavenumbers. We exclude a chemical decomposition as the main reason for this behavior since upon rereduction, the original band was restored to about $70 \%$ of its original intensity. A likely explanation is that the band of the oxidized form is significantly less intense than the al ready weak absorption of the Ru(II) starting compound. Similar observations have been made for Ru(II)-bound alkyny ${ }^{26 b}$ or cyani de ${ }^{48}$ ligands upon oxidation of the metal center. In summary, EPR spectroel ectrochemistry let us identify the oxidation of cations $\mathbf{3}$ as being a metal-centered process. The results of UV/vis and IR spectroelectrochemistry agree with this assignment. They do, however, not provide any information as to changes in the bonding mode within the unsaturated ligand upon oxidation.

\section{Experimental Section}

All manipulations were performed by standard Schlenk techniques under argon atmosphere. Dichloromethane, hexanes, and acetonitrile were dried by disitillation from $\mathrm{CaH}_{2}$. All solvents were either degassed by at least three freezepump-thaw cycles or saturated with argon prior to use. $\mathrm{RuCl}_{2^{-}}$ (dmso) ${ }_{4}^{49}$ and $\mathrm{RuCl}_{2}(\mathrm{dppm})_{2}{ }^{50}$ were obtained according to literature methods. Butadiyne was prepared from 1,4-dichloro2-butyne (Lancaster) on a $4 \mathrm{mmol}$ scale by a slight modification of a published procedure ${ }^{51}$ and isolated at $195 \mathrm{~K}$ as a white,

(48) Bignozzi, C. A.; Argazzi, R.; Schoonover, K. C.; Gordon, K. C.; Dyer, R. B.; Scandola, F. Inorg. Chem. 1992, 31, 5260.

(49) Evans, I. P.; Spencer, A.; Wilkinson, G. J . Chem. Soc., Dalton Trans. 1973, 204.

(50) Chaudret, B.; Commenges, G.; Poilblanc, R. J . Chem. Soc., Dalton Trans. 1984, 1635.

(51) Georgieff, K. K.; Richard, Y. Can. J . Chem. 1958, 36, 1280. 

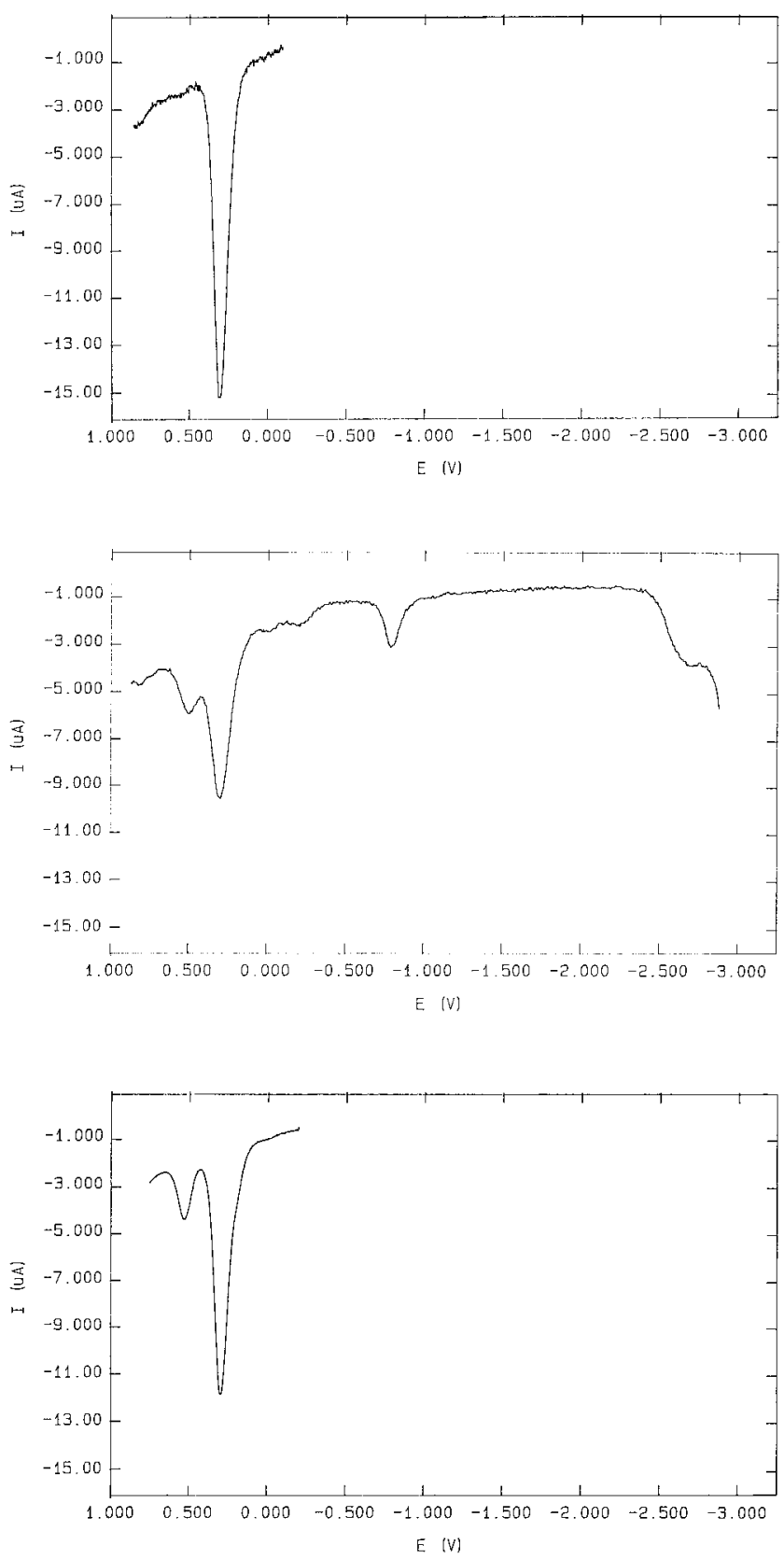

Figure 3. Square wave traces of the quinudidine derivative $3 c$ in DMF at v $=40 \mathrm{~Hz}$ : (a) oxidation only; (b) sweep initiated from cathodic of the reduction; (c) oxidation after addition of 1.2 equiv of quinuclidine (note the decreased peak height of the Ru(II/III) couple compared to (a) arising from the loss of chemical reversibility in the presence of the free amine).

crystalline solid. CAUTION: Butadiyne should be handled and stored under rigorous exclusion of air and at temperatures below $\mathbf{2 3 0} \mathbf{K}$. The purity of each batch was checked by NMR spectroscopy. Butadiyne was usually obtained in $88-93 \%$ purity, besides some ethanol (4-9\%) and less than 3\% trans-1-chlorobut-1-ene-3-yne (the product of monodehydrohalogenation of 1,4-dichloro-2-butyne), and used without further purification. It was stored at $213 \mathrm{~K}$. Before use, it was thawed in an ice/ $\mathrm{CaCl}_{2}$ cooling bath and the required amount (ca. $600 \mu \mathrm{L}$ ) transferred via a precooled pipet. The respective amines and deuterated solvents were obtained from commercial sources and distilled from $\mathrm{KOH}$ (amines) or $\mathrm{CaH}_{2}\left(\mathrm{CDCl}_{3}\right)$ before use. I nfrared spectra were obtained on a Perkin-EImer Paragon 1000 PC FT-IR instrument. ${ }^{1 \mathrm{H}}(250.13$ $\mathrm{MHz}),{ }^{13} \mathrm{C}(62.90 \mathrm{MHz})$, and ${ }^{31} \mathrm{P} \mathrm{NMR}$ spectra $(101.26 \mathrm{MHz})$

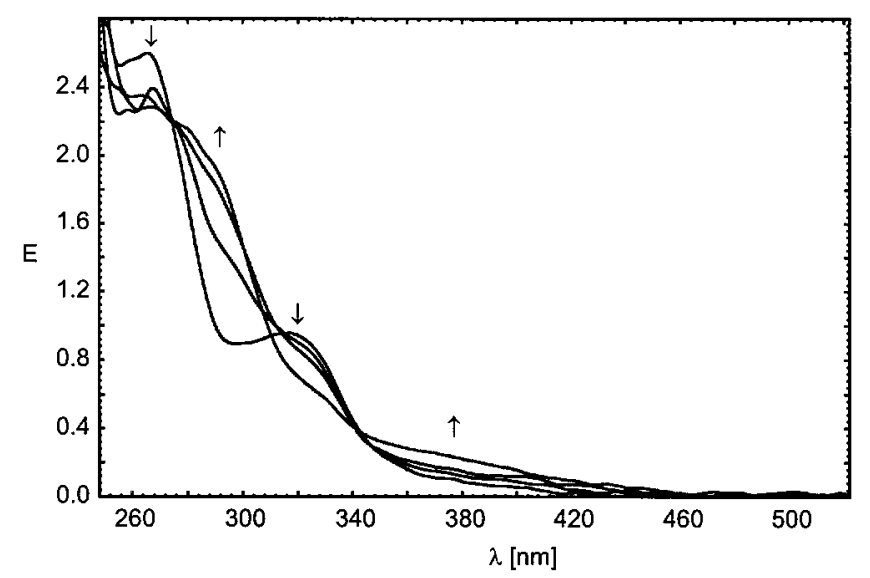

Figure 4. Spectroscopic changes upon in situ UV/vis spectroelectrochemistry of the $\mathrm{PhCH}_{2} \mathrm{NMe}_{2}$ derivative $\mathbf{3 f}$.

were recorded on a Bruker AC 250 spectrometer as $\mathrm{CDCl}_{3}$ solutions at $303 \mathrm{~K}$ or in the solvent indicated. The spectra were referenced to the residual protonated solvent $\left({ }^{1} \mathrm{H}\right)$, the solvent signal itself $\left({ }^{13} \mathrm{C}\right)$, or external $\mathrm{H}_{3} \mathrm{PO}_{4}\left({ }^{31} \mathrm{P}\right)$. If necessary, the assignment of ${ }^{13} \mathrm{C}$ NMR spectra was aided by DEPT-135 experiments. UV/vis spectra were obtained on a Shimadzu UV160 spectrometer or an Omega 10 spectrometer from Bruins Instruments in HELMA quartz cuvettes whith $1 \mathrm{~cm}$ optical path lengths. The ESR equipment consists of a Bruker ESP 3000 spectrometer equipped with a HP frequency counter 5350 $B$, a Bruker NMR gaussmeter ER 035 M, and a continuous flow cryostat ESR 900 from Oxford Instruments for lowtemperature work. Elemental analyses $(\mathrm{C}, \mathrm{H}, \mathrm{N})$ were performed at in-house facilities. All el ectrochemical experiments were performed in a home-built cylindrical, vacuum-tight onecompartment cell. A spiral-shaped Pt wire and a Ag wire as the counter and reference electrodes are sealed directly into opposite sides of the glass wall, while the respective working el ectrode (Pt or glassy carbon $1.1 \mathrm{~mm}$ polished with $0.25 \mu \mathrm{m}$ diamond paste (Buehler-Wirtz) before each experiment) is introduced via a Teflon screw cap with a suitable fitting. The cell may be attached to a conventional Schlenk line via two sidearms equipped with Teflon screw valves and allows experiments to be performed under an atmosphere of argon with approximately $2.5 \mathrm{~mL}$ of analyte solution. The solvents were obtained in the highest available purity from commercial sources $\left(\mathrm{CH}_{2} \mathrm{Cl}_{2}\right.$ and $1,2-\mathrm{C}_{2} \mathrm{H}_{4} \mathrm{Cl}_{2}$ from Fluka (Burdick \& J ackson Brand), $\mathrm{CH}_{3} \mathrm{CN}$ (HPLC Gradient Grade) from Roth, THF (99.9\%) from Aldrich) and either treated with alumina (2-5 mm particles for drying purposes from Fluka) or freshly distilled from $\mathrm{CaH}_{2}\left(\mathrm{CH}_{2} \mathrm{Cl}_{2}, 1,2-\mathrm{C}_{2} \mathrm{H}_{4} \mathrm{Cl}_{2}, \mathrm{CH}_{3} \mathrm{CN}\right)$ or $\mathrm{K}$ (THF) before use. $\mathrm{NBu}_{4} \mathrm{PF}_{6}(0.25 \mathrm{mM})$ was used as the supporting el ectrolyte. All potentials are referenced versus the ferrocene/ ferrocenium couple. Electrochemical data were acquired with a computer-controlled EG\&G model 273 potentiostat utilizing the EG\&G 250 software package. The OTTLE cell was also home-built and comprises a Pt-mesh working and counter electrode and a thin silver wire as a pseudo-reference electrode sandwiched between the $\mathrm{CaF}_{2}$ windows of a conventional liquid IR cell. The working electrode is positioned in the center of the spectrometer beam. Digital simulations of experimental CVs were performed with DigiSim (version 2.1) available from BAS. The procedure for simulation of the electron-transfer kinetics was as follows: We utilized experimental CVs that contained ferrocene and the respective analyte in concentrations that yielded very similar peak currents for the two couples. First, the experimental wave of the ferrocene couple was simulated. Values of D $\left(2.40 \mathrm{~cm}^{2} \mathrm{~s}^{-1}\right),{ }^{52} \mathrm{ks}_{\mathrm{s}}\left(6.8 \times 10^{6} \mathrm{~cm}\right.$

(52) Hershberger, J . W.; Klingler, R. J .; Kochi, J . J . Am. Chem. Soc. 1983, 105, 61. 
$\left.\mathrm{S}^{-1}\right)$, and $\alpha(0.49)^{53}$ were taken from the literature. Ohmic drop was induded such that the experimental peak-to-peak separation of the $\mathrm{Cp}_{2} \mathrm{Fe}^{0 /+}$ couple was reproduced over a range of sweep rates ranging from $\mathrm{v}=0.1$ to $2.5 \mathrm{~V} / \mathrm{s}$. N ext, the wave of the analyte was analyzed by changing the $k_{s}$ and $\alpha$ values until good agreement between simulated and experimental CVs was obtained over the entire range of sweep rates.

Synthesis of trans-[CIRu(dppm $)_{2}-\mathrm{C} \equiv \mathrm{C}-\mathrm{C}\left(\mathrm{NEt}_{3}\right)=$ $\left.\mathbf{C H}_{2}\right]^{+} \mathbf{P F}_{6}{ }^{-}$(3a). Solid cis-RuCl ${ }_{2}(\mathrm{dppm})_{2}(0.150 \mathrm{~g}, 0.159 \mathrm{mmol})$ and $\mathrm{NaPF}_{6}(0.107 \mathrm{~g}, 0.637 \mathrm{mmol})$ were suspended in a solution of excess butadiyne in $\mathrm{CH}_{2} \mathrm{Cl}_{2}(30 \mathrm{~mL})$. Within the next 40 min a color change from yel low to intense green was observed. $\mathrm{NEt}_{3}(135 \mu \mathrm{L}, 0.098 \mathrm{~g}, 0.097 \mathrm{mmol}$ ) was added by microliter syringe. The solution was allowed to stir at ambient temperature for $23 \mathrm{~h}$, filtered via a filter-paper-tipped cannula, and evaporated to dryness. The crude product was chromatographed on silica with $10: 1 \mathrm{CH}_{2} \mathrm{Cl}_{2} / \mathrm{CH}_{3} \mathrm{CN}$ as the eluant. The first green fraction was collected. The solvent was removed in vacuo and the residue washed with ether and recrystallized from $\mathrm{CH}_{2} \mathrm{Cl}_{2} / \mathrm{Et}_{2} \mathrm{O}$ (3:1). Yield: 58\%. ${ }^{1} \mathrm{H} \mathrm{NMR}(250.133 \mathrm{MHz})$ : $\delta 0.65$ (t, $\left.\mathrm{NCH}_{2} \mathrm{CH}_{3}, 9 \mathrm{H}, 3{ }_{\mathrm{H}-\mathrm{H}}=7.15 \mathrm{~Hz}\right), 2.46\left(\mathrm{q}, \mathrm{NCH}_{2}, 6 \mathrm{H}\right.$, 3) $\mathrm{H}-\mathrm{H}=7.15 \mathrm{~Hz}), 3.80\left(\mathrm{~d}, \mathrm{C}=\mathrm{CHH}, 1 \mathrm{H},{ }^{2} \mathrm{~J}-\mathrm{H}=3.04 \mathrm{~Hz}\right), 4.60$ (d, $\mathrm{C}=\mathrm{CHH}, 1 \mathrm{H},{ }^{2} \mathrm{~J}_{\mathrm{H}-\mathrm{H}}=3.04 \mathrm{~Hz}$ ), 4.90 (dquint, $\mathrm{CH}_{2}(\mathrm{dppm})$, $2 \mathrm{H}, \mathrm{J} H-\mathrm{H}=14.53 \mathrm{~Hz},{ }^{2} \mathrm{~J} \mathrm{P}_{\mathrm{H}}=4 \mathrm{~J}_{\mathrm{P}^{\prime}-\mathrm{H}}=4.32 \mathrm{~Hz}$ ), 5.15 (dquint, $\left.\mathrm{CH}_{2}(\mathrm{dppm}), 2 \mathrm{H}, \mathrm{J} \mathrm{H}-\mathrm{H}=14.53 \mathrm{~Hz},{ }^{2} \mathrm{~J}_{\mathrm{P}-\mathrm{H}}={ }^{4} \mathrm{~J}_{\mathrm{P}-\mathrm{H}}=4.43 \mathrm{~Hz}\right)$, 7.34-7.42 (m, aryl-H (dppm), 24H), 7.62 (m, aryl-H (dppm), $8 \mathrm{H}), 7.65\left(\mathrm{~m}\right.$, aryl-H (dppm), 8H). ${ }^{13} \mathrm{C}\left\{{ }^{1} \mathrm{H}\right\} \mathrm{NMR}(62.9 \mathrm{MHz}$, $\left.\mathrm{CD}_{3} \mathrm{CN}\right): \delta 7.87\left(\mathrm{NCH}_{2} \mathrm{CH}_{3}\right), 50.15$ (quint, $\mathrm{CH}_{2}(\mathrm{dppm}), \mathrm{N}_{\mathrm{p}-\mathrm{C}}$ $=10.8 \mathrm{~Hz}), 51.83\left(\mathrm{NCH}_{2}\right), 53.82(\mathrm{C} 3), 100.04(\mathrm{br}, \mathrm{C} 2), 111.35$ (C4), $128.12\left(\mathrm{~m}, \mathrm{p}-\mathrm{C}_{6} \mathrm{H}_{5}, \mathrm{~N} \mathrm{p}-\mathrm{c}=2.4 \mathrm{~Hz}\right), 128.89\left(\mathrm{~m}, \mathrm{p}-\mathrm{C}_{6} \mathrm{H}_{5}\right.$, $\mathrm{N}_{\mathrm{p}-\mathrm{C}}=2.3 \mathrm{~Hz}$ ), 130.17, $130.55\left(\mathrm{~m}-\mathrm{C}_{6} \mathrm{H}_{5}\right), 133.34$ (quint, o- $\mathrm{C}_{6} \mathrm{H}_{5}$, $\mathrm{N}_{\mathrm{P}-\mathrm{C}}=3.1 \mathrm{~Hz}$ ), 133.74 (quint, $\mathrm{o}_{-} \mathrm{C}_{6} \mathrm{H}_{5}, \mathrm{~N}_{\mathrm{P}-\mathrm{C}}=2.9 \mathrm{~Hz}$ ), 134.10 (quint, ipso- $\mathrm{C}_{6} \mathrm{H}_{5}, \mathrm{~N}$ p-C $=11.2 \mathrm{~Hz}$ ), 136.32 (quint, ipso- $\mathrm{C}_{6} \mathrm{H}_{5}$, $\mathrm{N}_{\mathrm{P}-\mathrm{C}}=11.0 \mathrm{~Hz}$ ), 146.22 (quint, $\mathrm{Cl}, \mathrm{J}_{\mathrm{P}-\mathrm{C}}=14.0 \mathrm{~Hz}$ ). ${ }^{31} \mathrm{P}\left\{{ }^{1} \mathrm{H}\right\}$ NMR (101.3 MHz): $\delta-5.8$ (s; P(dppm)), -143.5 (sept, $\mathrm{PF}_{6}{ }^{-}$,

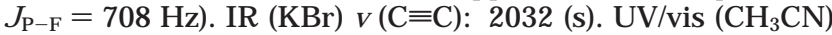
$\left(\lambda_{\max } \mathrm{nm}(\log \epsilon)\right): 209$ (4.79), 225 (4.73), 265 (4.50), 312 (3.88), 623 (2.39); $\left(\mathrm{CH}_{2} \mathrm{Cl}_{2}\right) 265$ (4.54), 319 (3.92), 624 (2.32). Anal. Calcd for $\mathrm{C}_{60} \mathrm{H}_{61} \mathrm{ClF}_{6} \mathrm{NP}_{5} \mathrm{Ru}$ : C, 59.98; $\mathrm{H}, 5.12 ; \mathrm{N}, 1.17$. Found: C, 59.55; $\mathrm{H}, 5.25 ; \mathrm{N}, 1.26$.

Complexes $\mathbf{3 b}$, 3d, and $\mathbf{3 f}-\mathbf{h}$ were prepared analogously with eluant mixtures and yields as indicated below. For $\mathbf{3 c}$ and $3 e$ chlorobenzene was used as solvent because of the high rectivity of the respective amines toward $\mathrm{CH}_{2} \mathrm{Cl}_{2}$; the reaction time was 3 days. No chromatography was required for the purification of $\mathbf{3 e}, \mathbf{g}$.

trans-[CIR u(dppm) $\left.)_{2}-\mathbf{C} \equiv \mathbf{C}-\mathbf{C}\left(\mathrm{NPr}_{3}\right)=\mathbf{C H}_{2}\right]^{+} \mathbf{P F}_{\mathbf{6}}{ }^{-}$(3b) From 1 (0.130 g, $0.138 \mathrm{mmol}), \mathrm{NaPF}_{6}(0.093 \mathrm{~g}, 0.553 \mathrm{mmol})$, excess butadiyne, and $\mathrm{NPr}_{3}(130 \mu \mathrm{L}, 0.100 \mathrm{~g}, 0.695 \mathrm{mmol}) 96$ mg (56\%) of $\mathbf{3 b}$ was obtained as green microcrystals after chromatography $\left(\mathrm{CH}_{2} \mathrm{Cl}_{2} / \mathrm{CH}_{3} \mathrm{CN}, 10: 1\right)$ and reprecipitation from $\mathrm{CH}_{2} \mathrm{Cl}_{2} / \mathrm{Et}_{2} \mathrm{O}$. ${ }^{1 \mathrm{H}} \mathrm{NMR}: \delta 0.70\left(\mathrm{t}, \mathrm{CH}_{3}(\mathrm{Pr}), 9 \mathrm{H},{ }^{3} \mathrm{~J}_{\mathrm{H}-\mathrm{H}}=\right.$ $7.14 \mathrm{~Hz}), 1.14\left(\mathrm{~m}, \mathrm{CH}_{2}(\mathrm{Pr}), 6 \mathrm{H}\right), 2.47\left(\mathrm{~m}, \mathrm{NCH}_{2}, 6 \mathrm{H}\right), 4.12(\mathrm{~d}$, $\mathrm{C}=\mathrm{CHH}, 1 \mathrm{H}, 2 \mathrm{~J}-\mathrm{H}=2.88 \mathrm{~Hz}$ ), 4.41 (dquint, $\mathrm{CH}_{2}(\mathrm{dppm}), 2 \mathrm{H}$, $\left.\mathrm{J} \mathrm{H}-\mathrm{H}=14.21 \mathrm{~Hz},{ }^{2} \mathrm{~J}_{\mathrm{P}-\mathrm{H}}=4 \mathrm{~J}_{\mathrm{P}^{\prime}-\mathrm{H}}=4.21 \mathrm{~Hz}\right), 4.68(\mathrm{~d}, \mathrm{C}=\mathrm{CHH}$, $1 \mathrm{H},{ }^{2} \mathrm{~J} \mathrm{H}-\mathrm{H}^{2}=2.88 \mathrm{~Hz}$ ), 4.92 (dquint, $\mathrm{CH}_{2}(\mathrm{dppm}), 2 \mathrm{H}, \mathrm{J} \mathrm{H}-\mathrm{H}=$ $\left.14.21 \mathrm{~Hz},{ }^{2} \mathrm{~J}-\mathrm{H}^{2}=4 \mathrm{~J}_{\mathrm{p}-\mathrm{H}}=4.23 \mathrm{~Hz}\right), 7.04(\mathrm{~m}, \operatorname{aryl}-\mathrm{H}(\mathrm{dppm})$, $8 \mathrm{H}), 7.16-7.33(\mathrm{~m}$, aryl-H (dppm), 24H), $7.56(\mathrm{~m}$, aryl-H (dppm), 8H $).{ }^{13} \mathrm{C}\left\{{ }^{1} \mathrm{H}\right\}$ NMR: $\delta 11.02\left(\mathrm{CH}_{3}\right), 15.42\left(\mathrm{CH}_{2}(\mathrm{Pr})\right)$, 52.10 (quint, $\mathrm{CH}_{2}(\mathrm{dppm}), \mathrm{N}_{\mathrm{P}-\mathrm{C}}=11.6 \mathrm{~Hz}$ ), 53.77 (C3), 59.31 $\left(\mathrm{NCH}_{2}\right), 103.70$ (br, C2), 110.17 (C4), 127.53 (m, p- ${ }_{6} \mathrm{H}_{5}, \mathrm{~N}_{\mathrm{P}-\mathrm{C}}$ $=1.9 \mathrm{~Hz}), 128.31\left(\mathrm{~m}, \mathrm{p}-\mathrm{C}_{6} \mathrm{H}_{5}, \mathrm{~N}_{\mathrm{p}-\mathrm{C}}=2.2 \mathrm{~Hz}\right), 129.47,130.1$ $\left(\mathrm{m}-\mathrm{C}_{6} \mathrm{H}_{5}\right), 133.04,133.08\left(\mathrm{~m}, \mathrm{o}-\mathrm{C}_{6} \mathrm{H}_{5}\right), 134.69$ (quint, ipso- $\mathrm{C}_{6} \mathrm{H}_{5}$ $\mathrm{N}_{\mathrm{P}-\mathrm{C}}=11.8 \mathrm{~Hz}$ ), 136.24 (quint, ipso- $\mathrm{C}_{6} \mathrm{H}_{5}, \mathrm{~N}_{\mathrm{p}-\mathrm{C}}=10.6 \mathrm{~Hz}$ ), 146.03 (quint, $\mathrm{C} 1$, J $\mathrm{P}-\mathrm{C}=14.6 \mathrm{~Hz}$ ). ${ }^{31} \mathrm{P}\left\{{ }^{1} \mathrm{H}\right\} \mathrm{NMR} \delta-4.1(\mathrm{~s}$, $\mathrm{P}(\mathrm{dppm})),-143.5$ (sept, $\mathrm{PF}_{6}{ }^{-}$, J $\left.\mathrm{P}-\mathrm{F}=708 \mathrm{~Hz}\right) . \mathrm{IR}(\mathrm{KBr}): \mathrm{v}(\mathrm{C} \equiv$ C) $2027(\mathrm{~m})$. UV/vis $\left(\mathrm{CH}_{3} \mathrm{CN}\right)\left(\lambda_{\max } \mathrm{nm}(\log \epsilon)\right): 216(4.79), 224$ (4.78), 265 (4.45), 315 (4.10), 625 (2.25); $\left(\mathrm{CH}_{2} \mathrm{Cl}_{2}\right) 265$ (4.57),

(53) J un, Z.; Wang, J .; Tai, Z.; J u, H. J . Electroanal. Chem. 1995 $381,231$.
322 (4.16), 675 (2.30). Anal. Calcd for $\mathrm{C}_{63} \mathrm{H}_{67} \mathrm{ClF}_{6} \mathrm{NP}_{5} \mathrm{Ru}$ : C 60.85; H, 5.43; N, 1.13. Found: C, 60.57; H, 5.24; N, 1.12.

trans-[CIRu(dppm) $\left.)_{2}-\mathbf{C} \equiv \mathbf{C}-\mathbf{C}\left(\mathbf{N}\left\{\mathbf{C H}_{2}\right\}_{3} \mathbf{C H}\right)=\mathbf{C H}_{2}\right]_{-}^{+}$ SbF $_{6}{ }^{-}$(3c). From $\mathbf{1}(0.175 \mathrm{~g}, 0.186 \mathrm{mmol}), \mathrm{NaSbF}_{6}(0.197 \mathrm{~g}$ $0.76 \mathrm{mmol})$, excess butadiyne, and quinuclidine $(0.102 \mathrm{~g}, 0.917$ $\mathrm{mmol}) 0.033 \mathrm{~g}(13.6 \%)$ of $3 \mathrm{c}$ was obtained after chromatography $\left(\mathrm{CH}_{2} \mathrm{Cl}_{2} / \mathrm{CH}_{3} \mathrm{CN}, 10: 1\right)$. No further purification was necessary. ${ }^{1 H} \mathrm{NMR}(250.133 \mathrm{MHz}): \delta 1.52\left(\mathrm{dt}, \mathrm{CH}_{2}, 6 \mathrm{H}, 3^{3} \mathrm{H}-\mathrm{H}=\right.$ $7.90 \mathrm{~Hz}, 3.21 \mathrm{~Hz}$ ), 1.89 (hpt, $\mathrm{CH}, 1 \mathrm{H}, 3 \mathrm{~J} \mathrm{H-H}=3.21 \mathrm{~Hz}$ ), 2.55 (t, $\mathrm{NCH}_{2}, 6 \mathrm{H}, 3 \mathrm{~J}_{\mathrm{H}-\mathrm{H}}=7.90 \mathrm{~Hz}$ ), 3.61 (d (br), $\mathrm{C}=\mathrm{CHH}, 1 \mathrm{H}$, 2) $\mathrm{H}-\mathrm{H}=3.02 \mathrm{~Hz}), 4.70\left(\mathrm{~d}, \mathrm{C}=\mathrm{CHH}, 1 \mathrm{H},{ }^{2} \mathrm{~J}-\mathrm{H}=3.02 \mathrm{~Hz}\right), 4.74$ (dquint, $\mathrm{CH}_{2}(\mathrm{dppm}), 2 \mathrm{H}, \mathrm{J} \mathrm{H}-\mathrm{H}=14.64 \mathrm{~Hz},{ }^{2} \mathrm{JP}_{\mathrm{P}} \mathrm{H}={ }^{4} \mathrm{~J}_{\mathrm{P}^{\prime}-\mathrm{H}}=$ $4.29 \mathrm{~Hz}$ ), 5.06 (dquint, $\mathrm{CH}_{2}(\mathrm{dppm}), 2 \mathrm{H}, \mathrm{J} \mathrm{H}-\mathrm{H}=14.53 \mathrm{~Hz},{ }^{2} \mathrm{~J} \mathrm{P}-\mathrm{H}$ $\left.=4 \mathrm{f}_{\mathrm{p}^{\prime}-\mathrm{H}}=4.44 \mathrm{~Hz}\right), 7.13(\mathrm{~m}$, aryl $-\mathrm{H}(\mathrm{dppm}), 8 \mathrm{H}), 7.24-7.33$ (m, aryl-H (dppm), 24H), $7.52\left(\mathrm{~m}\right.$, aryl-H (dppm), 8H). ${ }^{13} \mathrm{C}-$ $\left\{{ }^{1} \mathrm{H}\right\}$ NMR $\left(62.9 \mathrm{MHz}, \mathrm{CD}_{2} \mathrm{Cl}_{2}\right): \delta 19.6(\mathrm{CH}), 24.4\left(\mathrm{CH}_{2}\right), 50.1$ (quint, $\left.\mathrm{CH}_{2}(\mathrm{dppm}), \mathrm{N}_{\mathrm{P}-\mathrm{C}}=10.6 \mathrm{~Hz}\right), 55.2\left(\mathrm{NCH}_{2}\right), 103.1$ (br, C2), 107.2 (C4), 128.3, 128.8 (quint, $\mathrm{p}-\mathrm{C}_{6} \mathrm{H}_{5}, \mathrm{~N} \mathrm{~N}_{-\mathrm{C}}=2.4 \mathrm{~Hz}$ ), 130.2, $130.4\left(m-\mathrm{C}_{6} \mathrm{H}_{5}\right), 133.5$ (quint, $0-\mathrm{C}_{6} \mathrm{H}_{5}, \mathrm{~N}_{\mathrm{p}-\mathrm{C}}=3.1 \mathrm{~Hz}$ ), 134.0 (quint, $\mathrm{o}_{-} \mathrm{C}_{6} \mathrm{H}_{5}, \mathrm{~N}_{\mathrm{P}-\mathrm{C}}=2.8 \mathrm{~Hz}$ ), $134.1,135.9$ (quint, ipso$\mathrm{C}_{6} \mathrm{H}_{5}, \mathrm{~N}_{\mathrm{P}-\mathrm{C}}=11.1 \mathrm{~Hz}$ ), 146.1 (quint, $\mathrm{C} 1, \mathrm{~J} \mathrm{P}-\mathrm{C}=14.4 \mathrm{~Hz}$ ). ${ }^{31} \mathrm{P}$ $\left\{{ }^{1} \mathrm{H}\right\}$ NMR (101.3 MHz): $\delta-6.0$ (s; P (dppm). IR (KBr): v (C $\equiv$ C) 2032 (s). UV/vis $\left(\mathrm{CH}_{3} \mathrm{CN}\right)\left(\lambda_{\max } \mathrm{nm}(\log \epsilon)\right): 226$ (4.653), 265 (4.491), 311 (3.881), 390(sh) (3.079), 509(sh) (2.663), 627 (2.707), 740 (2.398); $\left(\mathrm{CH}_{2} \mathrm{Cl}_{2}\right) 265$ (4.531), 320 (3.908), 395(sh) (3.079), 503 (2.591), 626 (2.653), 744 (2.311). Anal. Calcd for $\mathrm{C}_{61} \mathrm{H}_{59} \mathrm{ClF}_{6} \mathrm{NP}_{4} \mathrm{RuSb}: \mathrm{C}, 56.25 ; \mathrm{H}, 4.57 ; \mathrm{N}, 1.08$. Found: $\mathrm{C}$, 55.65; H, 4.45; N, 1.06.

trans-[CIRu(dppm $\left.)_{2}-\mathrm{C} \equiv \mathrm{C}-\mathrm{C}\left(\mathrm{C}_{2} \mathrm{H}_{5} \mathbf{N}\left(\mathrm{CH}_{2}\right)_{4} \mathrm{O}\right)=\mathrm{CH}_{2}\right]^{+}$ PF $_{6}{ }^{-}$(3d). From 1 (0.175 g, $\left.0.186 \mathrm{mmol}\right), \mathrm{KPF}_{6}(0.171 \mathrm{~g}, 0.93$ $\mathrm{mmol}$ ), excess butadiyne, and ethylmorpholine (115 $\mu \mathrm{L}, 0.104$ $\mathrm{g}, 0.903 \mathrm{mmol}) 0.080 \mathrm{~g}(35 \%)$ of $\mathbf{3 d}$ was obtained after chromatography $\left(\mathrm{CH}_{2} \mathrm{Cl}_{2} / \mathrm{CH}_{3} \mathrm{CN}, 12.5: 1\right)$, extraction of the solid obtained after removal of solvents into $\mathrm{CHCl}_{3}$, filtration, and drying in vacuo. ${ }^{1} \mathrm{H}$ NMR $\left(250.133 \mathrm{MHz}, \mathrm{CD}_{3} \mathrm{CN}\right): \delta 0.64$ $\left(\mathrm{t}, \mathrm{CH}_{3}, 3 \mathrm{H}, 3 \mathrm{~J}_{\mathrm{H}-\mathrm{H}}=7.18 \mathrm{~Hz}\right), 2.37\left(\mathrm{q}, \mathrm{CH}_{2}, 2 \mathrm{H}, 3 \mathrm{~J}_{\mathrm{H}-\mathrm{H}}=7.18\right.$ $\mathrm{Hz}$ ), 2.61 (ddd, $\mathrm{CH}_{2}, 2 \mathrm{H},{ }^{3} \mathrm{H}_{\mathrm{H}}=13.25,8.56,3.13$ ), 2.85 (ddd, $\mathrm{CH}_{2}, 2 \mathrm{H}, 3{ }^{3} \mathrm{H}-\mathrm{H}=13.40,4.17,3.13$ ), 3.17 (ddd, $\mathrm{CH}_{2}, 2 \mathrm{H},{ }^{3} \mathrm{~J}-\mathrm{H}$ $=13.40,8.56,2.16), 3.37$ (ddd, $\mathrm{CH}_{2}, 2 \mathrm{H}, 3 \mathrm{~J}_{\mathrm{H}-\mathrm{H}}=13.25,4.17$, 2.16), 3.97 (d (br), $\left.\mathrm{C}=\mathrm{CHH}, 1 \mathrm{H},{ }^{2} \mathrm{~J} H-\mathrm{H}=3.17 \mathrm{~Hz}\right), 4.43(\mathrm{~d}, \mathrm{C}=$ $\mathrm{CHH}, 1 \mathrm{H}, 2 \mathrm{~J} H-\mathrm{H}=3.17 \mathrm{~Hz}$ ), 4.69 (dquint, $\mathrm{CH}_{2}(\mathrm{dppm}), 2 \mathrm{H}, \mathrm{J} \mathrm{H}-\mathrm{H}$ $=14.79 \mathrm{~Hz},{ }^{2} \mathrm{~J}_{\mathrm{P}-\mathrm{H}}=4 \mathrm{~J}_{\mathrm{P}^{\prime}-\mathrm{H}}=4.43 \mathrm{~Hz}$ ), 5.13 (dquint, $\mathrm{CH}_{2^{-}}$ (dppm), $\left.2 \mathrm{H}, \mathrm{J}_{\mathrm{H}-\mathrm{H}}=14.79 \mathrm{~Hz},{ }^{2} \mathrm{~J}_{\mathrm{P}-\mathrm{H}}=4 \mathrm{~J}_{\mathrm{p}-\mathrm{H}}=4.50 \mathrm{~Hz}\right), 7.20$ (m, aryl-H (dppm), 8H), 7.32-7.51 (m, aryl-H (dppm), 24H), $7.63\left(\mathrm{~m}\right.$, aryl-H (dppm), 8H ). ${ }^{13} \mathrm{C}\left\{{ }^{1} \mathrm{H}\right\} \mathrm{NMR}\left(62.9 \mathrm{MHz}, \mathrm{CD}_{3^{-}}\right.$ $\mathrm{CN})$ : $\delta 7.75\left(\mathrm{CH}_{3}\right), 49.9$ (quint, $\left.\mathrm{CH}_{2}(\mathrm{dppm}), \mathrm{N}_{\mathrm{p}-\mathrm{C}}=11.3 \mathrm{~Hz}\right)$, $57.4\left(\mathrm{CH}_{2}\right), 58.9(\mathrm{C} 3), 61.6\left(\mathrm{CH}_{2}\right), 100.0$ (quint, $\mathrm{C} 2,3 \mathrm{~J} \mathrm{p}-\mathrm{C}=$ 1.6), 112.5 (C4), 128.7, 129.4 (quint, $\mathrm{p}-\mathrm{C}_{6} \mathrm{H}_{5}, \mathrm{~N}_{\mathrm{p}-\mathrm{C}}=2.6 \mathrm{~Hz}$ ), $130.7,131.1\left(\mathrm{~m}_{-} \mathrm{C}_{6} \mathrm{H}_{5}\right), 133.8,134.1$ (quint, $\mathrm{o}-\mathrm{C}_{6} \mathrm{H}_{5}, \mathrm{~N} \mathrm{p}-\mathrm{C}=3.2$ $\mathrm{Hz}$ ), 134.9, 136.7 (quint, ipso- $\mathrm{C}_{6} \mathrm{H}_{5}, \mathrm{~N}_{\mathrm{P}-\mathrm{C}}=11.1 \mathrm{~Hz}$ ), 146.9 (quint, $\mathrm{C} 1$, J $\mathrm{P}-\mathrm{C}=14.8 \mathrm{~Hz}) .{ }^{31} \mathrm{P}\left\{{ }^{1} \mathrm{H}\right\}-\mathrm{NMR}(101.3 \mathrm{MHz}): \delta-6.2$ (s; $\mathrm{P}(\mathrm{dppm}),-143.6$ (sept, $\mathrm{PF}_{6}{ }^{-}$, J $\left.\mathrm{P}-\mathrm{F}=708 \mathrm{~Hz}\right)$. IR (KBr): V $(\mathrm{C} \equiv \mathrm{C}) 2027$ (s); UV/vis $\left(\mathrm{CH}_{3} \mathrm{CN}\right)\left(\lambda_{\max } \mathrm{nm}(\log \epsilon)\right): 228(4.478)$, 262 (4.491), 314 (3.968), 385(sh) (3.290), 506(sh) (2.857), 638 (3.342); $\left(\mathrm{CH}_{2} \mathrm{Cl}_{2}\right.$ ) 263 (4.556), 320 (3.332), 389(sh) (3.301), 512 (sh) (2.845), 643 (3.332). Anal. Calcd for $\mathrm{C}_{60} \mathrm{H}_{59} \mathrm{ClF}_{6} \mathrm{NOP}_{5} \mathrm{Ru}$ : C, 59.29; H, 4.89; N, 1.15. Found: C, 58.83; H, 4.76; N, 1.16 .

trans-[CIRu(dppm) $)_{2}-\mathbf{C} \equiv \mathbf{C}-\mathbf{C}\left(\mathrm{Me}_{3}\right.$ tacn $\left.)=\mathbf{C H}_{2}\right]^{+} \mathbf{S b F}_{\mathbf{6}}$ (3e). 3e was obtained from 1 ( $0.162 \mathrm{~g}, 0.172 \mathrm{mmol}), \mathrm{NaSbF}_{6}$ $(0.186 \mathrm{~g}, 0.719 \mathrm{mmol})$, excess butadiyne, and Mestacn (70 $\mu \mathrm{L}$, $0.0619 \mathrm{~g}, 0.36 \mathrm{mmol}$ ) in $\mathrm{PhCl}$. The crude product was dissolved in the minimum amount of $\mathrm{CH}_{2} \mathrm{Cl}_{2}$ and slowly added to vigorously stirred $\mathrm{Et}_{2} \mathrm{O}(20 \mathrm{~mL})$. The mother liquors were removed by filter cannula and the remaining green powder dried in vacuo. After repeating this procedure twice, the product was essentially pure. Yield: $0.176 \mathrm{~g}(80 \%) .{ }^{1} \mathrm{H}$ NMR: $\delta 2.20\left(\mathrm{~s}, \mathrm{NCH}_{3}, 6 \mathrm{H}\right), 2.24\left(\mathrm{~s}, \mathrm{NCH}_{3}, 3 \mathrm{H}\right), 2.56-2.82\left(\mathrm{~m}, \mathrm{NCH}_{2}\right.$ $12 \mathrm{H}$ ), $3.84\left(\mathrm{~d}, \mathrm{C}=\mathrm{CHH}, 1 \mathrm{H},{ }^{2} \mathrm{~J} \mathrm{H}-\mathrm{H}=2.83 \mathrm{~Hz}\right.$ ), 4.65 (dquint, $\mathrm{CH}_{2}(\mathrm{dppm}), \mathrm{J}_{\mathrm{H}-\mathrm{H}}=14.67 \mathrm{~Hz}$, 2 $\left.\mathrm{P}-\mathrm{H}=4 \mathrm{~J}_{\mathrm{P}^{\prime}-\mathrm{H}}=4.00 \mathrm{~Hz}, 2 \mathrm{H}\right)$, 4.69 (br, $\mathrm{C}=\mathrm{CHH}, 1 \mathrm{H}$ ), 5.03 (dquint, $\mathrm{CH}_{2}(\mathrm{dppm})$, J $\mathrm{H}-\mathrm{H}=14.67$ $\left.\mathrm{Hz},{ }^{2} \mathrm{~J}_{\mathrm{P}-\mathrm{H}}={ }^{4} \mathrm{f}^{\prime}-\mathrm{H}=4.20 \mathrm{~Hz}, 2 \mathrm{H}\right), 7.07$ (t, aryl-H (dppm), 
$8 \mathrm{H}), 7.17-7.35(\mathrm{~m}$, aryl-H (dppm), 24H), 7.51 (m, aryl-H (dppm), 8H). ${ }^{13} \mathrm{C}\left\{{ }^{1} \mathrm{H}\right\}$ NMR: $\delta 26.8\left(\mathrm{NCH}_{2}\right), 47.59\left(\mathrm{NCH}_{3}\right)$, $49.56\left(\mathrm{~N}^{+} \mathrm{CH}_{3}\right), 50.14$ (quint, $\left.\mathrm{CH}_{2}(\mathrm{dppm}), \mathrm{N}_{\mathrm{P}-\mathrm{C}}=11.3 \mathrm{~Hz}\right)$, $54.70\left(\mathrm{NCH}_{2}\right), 57.90(\mathrm{C} 3), 59.18\left(\mathrm{NCH}_{2}\right), 99.58$ (br, C2), 108.17 $\left(\mathrm{C}=\mathrm{CH}_{2}\right.$ ), 127.66 (quint, $\mathrm{p}-\mathrm{C}_{6} \mathrm{H}_{5}, \mathrm{~N}-\mathrm{C}=1.9 \mathrm{~Hz}$ ), 128.42 (quint, $\mathrm{p}-\mathrm{C}_{6} \mathrm{H}_{5}, \mathrm{~N}_{\mathrm{p}-\mathrm{C}}=2.0 \mathrm{~Hz}$ ), 129.65, $130.08\left(\mathrm{~m}-\mathrm{C}_{6} \mathrm{H}_{5}\right), 132.92$ (quint, o- $\mathrm{C}_{6} \mathrm{H}_{5}, \mathrm{~N}$ P-C $=2.5 \mathrm{~Hz}$ ), 133.15 (quint, ipso- $\mathrm{C}_{6} \mathrm{H}_{5}, \mathrm{~N}_{\mathrm{p}-\mathrm{C}}=11.4$ $\mathrm{Hz}$ ), 133.39 (quint, $\mathrm{o}-\mathrm{C}_{6} \mathrm{H}_{5}, \mathrm{~N}_{\mathrm{p}-\mathrm{C}}=2.9 \mathrm{~Hz}$ ), 135.50 (quint, ipso$\mathrm{C}_{6} \mathrm{H}_{5}, \mathrm{~N}_{\mathrm{P}-\mathrm{C}}=11.1 \mathrm{~Hz}$ ), 144.7 (quint, $\mathrm{Cl}$, J $\mathrm{P}-\mathrm{C}=14.5 \mathrm{~Hz}$ ). ${ }^{31 \mathrm{P}-}$ $\left\{{ }^{1} \mathrm{H}\right\}$ NMR: $\delta-6.3(\mathrm{~s}, \mathrm{P}(\mathrm{dppm}))$. IR $(\mathrm{KBr}): \mathrm{v}(\mathrm{C} \equiv \mathrm{C}) 2037(\mathrm{~m})$. UV/vis $\left(\mathrm{CH}_{3} \mathrm{CN}\right)\left(\lambda_{\max } \mathrm{nm}(\log \epsilon)\right): 226$ (4.615), 262 (4.328), 310 (3.732), 399(sh) (3.301), 627 (2.954), 710 (2.672), 811 (2.371); $\left(\mathrm{CH}_{2} \mathrm{Cl}_{2}\right) 263$ (4.279), 317 (3.699), 405(sh) (3.283), 636 (2.954), 710(sh) (2.686), 806(sh) (2.392). Anal. Calcd for $\mathrm{C}_{63} \mathrm{H}_{67} \mathrm{ClF}_{6} \mathrm{~N}_{3} \mathrm{P}_{4-}$ RuSb: C, 55.54; H, 4.96; N, 3.08. Found: C, 55.67; H, 5.01; N, 3.13.

[CIRu(dppm) $\left.)_{2}-\mathrm{C} \equiv \mathrm{C}-\mathrm{C}\left(\mathrm{NMe}_{2} \mathrm{CH}_{2} \mathrm{Ph}\right)=\mathrm{CH}_{2}\right]^{+} \mathrm{PF}_{6}{ }^{-}$(3f). 3f was prepared from $\mathbf{1}(0.155 \mathrm{~g}, 0.165 \mathrm{mmol}), \mathrm{NaPF}_{6}(0.112$ g, $0.667 \mathrm{mmol})$, excess butadiyne, and $\mathrm{PhCH}_{2} \mathrm{NMe}_{2}(150 \mu \mathrm{L}$, $0.135 \mathrm{~g}, 1.0 \mathrm{mmol}$ ) and chromatography on neutral alumina with $\mathrm{CH}_{2} \mathrm{Cl}_{2} / \mathrm{CH}_{3} \mathrm{CN}$ (7.5:1). After removal of solvents and washing the remaining solid with pentane pure $\mathbf{3 f}$ was obtained. Yield: $0.086 \mathrm{~g}(42 \%)$. ${ }^{1} \mathrm{H}$ NMR: $\delta 2.18\left(\mathrm{~s}, \mathrm{NCH}_{3}, 6 \mathrm{H}\right)$, $3.40\left(\mathrm{~s}, \mathrm{NCH}_{2}, 2 \mathrm{H}\right), 3.66$ (br, $\left.\mathrm{C}=\mathrm{CHH}, 1 \mathrm{H}\right), 4.39(\mathrm{~d}, \mathrm{C}=\mathrm{CHH}$, $1 \mathrm{H},{ }^{2} \mathrm{~J} \mathrm{H}-\mathrm{H}=3.09 \mathrm{~Hz}$ ), 4.87 (dquint, $\mathrm{CH}_{2}\left(\right.$ dppm), $\mathrm{J}_{\mathrm{H}-\mathrm{H}}=14.80$ $\mathrm{Hz},{ }^{2} \mathrm{~J}_{\mathrm{P}-\mathrm{H}}=4 \mathrm{~J}_{\mathrm{P}^{\prime}-\mathrm{H}}=4.45 \mathrm{~Hz}, 2 \mathrm{H}$ ), 5.19 (dquint, $\mathrm{CH}_{2}$ (dppm), $\left.\mathrm{J}_{\mathrm{H}-\mathrm{H}}=14.80 \mathrm{~Hz},{ }^{2} \mathrm{~J}_{\mathrm{P}-\mathrm{H}}={ }^{4} \mathrm{~J}_{\mathrm{P}^{\prime}-\mathrm{H}}=4.48 \mathrm{~Hz}, 2 \mathrm{H}\right), 6.84(\mathrm{dd}$, $\left.\operatorname{aryl}-\mathrm{H}(\mathrm{Bz}), \mathrm{J}_{\mathrm{H}-\mathrm{H}}=8.47,1.45 \mathrm{~Hz}\right), 7.21$ (t, aryl $-\mathrm{H}(\mathrm{dppm})$, $\left.8 \mathrm{H}, 3 \mathrm{~J}_{\mathrm{H}-\mathrm{H}}=7.41 \mathrm{~Hz}\right), 7.32\left(\mathrm{t}, \operatorname{aryl}-\mathrm{H}(\mathrm{dppm}), 8 \mathrm{H}, 3 \mathrm{~J}_{\mathrm{H}-\mathrm{H}}=\right.$ $7.15 \mathrm{~Hz}), 7.35-7.39(\mathrm{~m}, \operatorname{aryl}-\mathrm{H}(\mathrm{dppm})$, aryl-H (Bz), 11H), $7.44(\mathrm{~m}, \operatorname{aryl}-\mathrm{H}(\mathrm{dppm}), 8 \mathrm{H}), 7.69(\mathrm{~m}, \operatorname{aryl}-\mathrm{H}(\mathrm{dppm}), 8 \mathrm{H})$. ${ }^{13} \mathrm{C}\left\{{ }^{1} \mathrm{H}\right\} \mathrm{NMR}\left(\mathrm{CD}_{3} \mathrm{CN}\right): \delta 49.44$ (quint, $\mathrm{CH}_{2}(\mathrm{dppm}), \mathrm{N}_{\mathrm{p}-\mathrm{C}}=$ $11.24 \mathrm{~Hz}), 50.69\left(\mathrm{NCH}_{3}\right), 55.31(\mathrm{C} 3), 67.52\left(\mathrm{NCH}_{2}\right), 100.78$ (quint, $\mathrm{C} 2$, J $\mathrm{P}_{-\mathrm{C}}=1.2 \mathrm{~Hz}$ ), $109.27\left(\mathrm{C}=\mathrm{CH}_{2}\right), 127.66$ (quint, $\mathrm{p}-\mathrm{C}_{6} \mathrm{H}_{5}, \mathrm{~N}$ p-c $\left.=2.3 \mathrm{~Hz}\right), 128.76\left(\mathrm{C}_{\text {ipso }}(\mathrm{Bz})\right), 129.09(\mathrm{CH}(\mathrm{Bz}))$, 129.14 (quint, $\mathrm{p}-\mathrm{C}_{6} \mathrm{H}_{5}, \mathrm{~N}$ - $\left.\mathrm{C}=2.2 \mathrm{~Hz}\right), 130.78,131.08\left(\mathrm{~m}-\mathrm{C}_{6} \mathrm{H}_{5}\right)$, 131.19, 132.54 (CH (Bz)), 132.46, 133.70 (quint, o- $\mathrm{C}_{6} \mathrm{H}_{5}, \mathrm{~N}_{\mathrm{P}-\mathrm{C}}$ $=3.1 \mathrm{~Hz}$ ), 135.05, 136.81 (quint, ipso- $\mathrm{C}_{6} \mathrm{H}_{5}, \mathrm{~N}_{\mathrm{p}-\mathrm{C}}=11.1 \mathrm{~Hz}$ ), 146.62 (quint, $\mathrm{C} 1$, J $\mathrm{P}-\mathrm{C}=14.6 \mathrm{~Hz}) .{ }^{31} \mathrm{P}\left\{{ }^{1} \mathrm{H}\right\} \mathrm{NMR}: \delta-5.9(\mathrm{~s}$, $\mathrm{P}(\mathrm{dppm})),-143.8$ (sept, $\mathrm{PF}_{6}{ }^{-}$, J $\left.\mathrm{P}-\mathrm{F}=706 \mathrm{~Hz}\right) . \mathrm{IR}(\mathrm{KBr}): \mathrm{v}(\mathrm{C} \equiv$ C) $2033(\mathrm{~m}) . \mathrm{UV} / \mathrm{vis}\left(\mathrm{CH}_{3} \mathrm{CN}\right)\left(\lambda_{\max } \mathrm{nm}(\log \epsilon)\right): 205(4.760)$, 223 (4.585), 264 (4.394), 316 (4.071), 493(sh) (2.772), 628 (2.506); $\left(\mathrm{CH}_{2} \mathrm{Cl}_{2}\right) 265$ (4.540), 321 (4.060), 495(sh) (2.640), 633 (2.404). Anal. Calcd for $\mathrm{C}_{63} \mathrm{H}_{59} \mathrm{ClF}_{6} \mathrm{NP}_{5} \mathrm{Ru}$ : C, 61.24; $\mathrm{H}, 4.81$; $\mathrm{N}, 1.13$. Found: $\mathrm{C}, 60.97 ; \mathrm{H}, 4.64 ; \mathrm{N}, 1.12$.

[CIRu(dppm) $\left.)_{2}-\mathbf{C} \equiv \mathbf{C}-\mathbf{C}\left\{\mathrm{NMe}_{2} \mathrm{CH}_{\mathbf{2}}(\mathbf{3}-\mathrm{OMePh})\right\}=\mathrm{CH}_{2}\right]^{+}$ PF $_{6}{ }^{-}$(3g). $\mathbf{3 g}$ was prepared from $\mathbf{1}(0.172 \mathrm{~g}, 0.186 \mathrm{mmol}), \mathrm{KPF}_{6}$ $(0.171 \mathrm{~g}, 0.930 \mathrm{mmol})$, excess butadiyne, and 3-methoxybenzyl$\mathrm{N}, \mathrm{N}$-dimethylamine $(125 \mu \mathrm{L}, 0.123 \mathrm{~g}, 0.744 \mathrm{mmol})$ in $50 \mathrm{~mL}$ of $\mathrm{CH}_{2} \mathrm{Cl}_{2} / \mathrm{PhCl}$ (1:4). After 3 days the solution was filtered and the solvent removed in vacuo. The resulting gray-green powder was thoroughly washed with ether and dried in vacuo to give pure 3f. Yield: $0.207 \mathrm{~g}(88 \%)$. ${ }^{1} \mathrm{H}$ NMR $\delta 2.17\left(\mathrm{~s}, \mathrm{NCH}_{3}\right.$, $6 \mathrm{H}), 3.38\left(\mathrm{~s}, \mathrm{NCH}_{2}, 2 \mathrm{H}\right), 3.75\left(\mathrm{~d}(\mathrm{br}), \mathrm{C}=\mathrm{CHH}, 1 \mathrm{H},{ }^{2} \mathrm{~J} \mathrm{H}-\mathrm{H}=3.05\right.$ $\mathrm{Hz}), 3.80\left(\mathrm{~s}, \mathrm{OCH}_{3}, 3 \mathrm{H}\right), 4.45\left(\mathrm{~d}, \mathrm{C}=\mathrm{CHH}, 1 \mathrm{H},{ }^{2} \mathrm{~J} \mathrm{H}_{\mathrm{H}}=3.05\right.$ $\mathrm{Hz}$ ), 4.87 (dquint, $\mathrm{CH}_{2}(\mathrm{dppm}), \mathrm{J} \mathrm{H}-\mathrm{H}=14.76 \mathrm{~Hz},{ }^{2} \mathrm{~J} \mathrm{P}-\mathrm{H}=4 \mathrm{~J}^{\prime}-\mathrm{H}$ $=4.42 \mathrm{~Hz}, 2 \mathrm{H}$ ), 5.18 (dquint, $\mathrm{CH}_{2}(\mathrm{dppm}), 2 \mathrm{H}, \mathrm{J}_{\mathrm{H}-\mathrm{H}}=14.80$ $\left.\mathrm{Hz}^{2}{ }^{2} \mathrm{P}-\mathrm{H}=4 \mathrm{f}_{\mathrm{p}^{\prime}-\mathrm{H}}=4.52 \mathrm{~Hz}\right), 6.54\left(\mathrm{dd}, \mathrm{aryl}-\mathrm{H}(\mathrm{Bz}), 1 \mathrm{H}, \mathrm{J}_{\mathrm{H}-\mathrm{H}}\right.$ $=2.65,1.53 \mathrm{~Hz}$ ), 6.38 (ddd, aryl-H (Bz), $1 \mathrm{H}, \mathrm{J}_{\mathrm{H}-\mathrm{H}}=7.62,1.53$, $0.92 \mathrm{~Hz}$ ), 7.01 (ddd, aryl-H (Bz), $1 \mathrm{H}, \mathrm{J}_{\mathrm{H}-\mathrm{H}}=8.37,2.65,0.92$ $\mathrm{Hz}), 7.21$ (m, aryl-H (dppm, Bz), 17H), 7.34 (t, aryl-H (dppm), 8H), 7.44 (m, aryl-H (dppm), 8H), 7.68 (m, aryl-H (dppm), $8 \mathrm{H}) .{ }^{13} \mathrm{C}\left\{{ }^{1} \mathrm{H}\right\}$ NMR $\left(\mathrm{CD}_{3} \mathrm{CN}\right): \delta 49.8$ (quint, $\mathrm{CH}_{2}(\mathrm{dppm}), \mathrm{N}_{\mathrm{P}-\mathrm{C}}$ $=11.3 \mathrm{~Hz}), 50.9\left(\mathrm{OCH}_{3}\right), 55.36(\mathrm{C} 3), 56.2\left(\mathrm{NMe}_{2}\right), 67.5\left(\mathrm{NCH}_{2}\right)$, 100.9 (quint, $\mathrm{C} 2, \mathrm{~J}-\mathrm{P}=1.2 \mathrm{~Hz}), 109.1\left(\mathrm{C}=\mathrm{CH}_{2}\right), 115.9,119.4$, 124.9 (CH (Bz)), 128.9, 129.6 (quint, $\mathrm{p}-\mathrm{C}_{6} \mathrm{H}_{5}, \mathrm{~N} \mathrm{p}_{-\mathrm{C}}=2.37 \mathrm{~Hz}$ ),

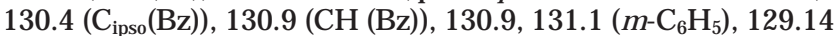
(quint, $\mathrm{p}-\mathrm{C}_{6} \mathrm{H}_{5}, \mathrm{~N}_{\mathrm{p}-\mathrm{C}}=2.2 \mathrm{~Hz}$ ), 133.9, 134.2 (quint, $\mathrm{o}-\mathrm{C}_{6} \mathrm{H}_{5}$, $\mathrm{N}_{\mathrm{P}-\mathrm{C}}=3.16 \mathrm{~Hz}$ ), 135.1, 136.8 (quint, ipso- $\mathrm{C}_{6} \mathrm{H}_{5}, \mathrm{~N}_{\mathrm{P}-\mathrm{C}}=11.05$ $\mathrm{Hz}$ ), 147.1 (quint, $\mathrm{C} 1$, J $\mathrm{P}-\mathrm{C}=14.5 \mathrm{~Hz}$ ), 160.5 ( $\mathrm{C}_{\text {ipso }}(\mathrm{Bz})$ ). ${ }^{31} \mathrm{P}-$ $\left\{{ }^{1} \mathrm{H}\right\}$ NMR: $\delta-5.9(\mathrm{~s}, \mathrm{P}(\mathrm{dppm})),-143.8$ (sept, $\mathrm{PF}_{6}{ }^{-}, \mathrm{J}_{\mathrm{P}-\mathrm{F}}=$
$706.3 \mathrm{~Hz})$. IR ( $\mathrm{KBr}): \mathrm{v}(\mathrm{C} \equiv \mathrm{C}) 2032(\mathrm{~m}) . \mathrm{UV} / \mathrm{vis}\left(\mathrm{CH}_{3} \mathrm{CN}\right)\left(\lambda_{\max }\right.$ $\mathrm{nm}(\log \epsilon)): 229$ (4.740), 266 (4.614), 314 (4.009), 393(sh) (2.940); $\left(\mathrm{CH}_{2} \mathrm{Cl}_{2}\right) 267$ (4.609), 319 (4.015), 393(sh) (3.0325). Anal. Calcd for $\mathrm{C}_{64} \mathrm{H}_{61} \mathrm{ClF}_{6} \mathrm{NP}_{5} \mathrm{ORu}$ : C, 60.74; $\mathrm{H}, 4.86 ; \mathrm{N}, 1.11$. Found: $\mathrm{C}, 60.21 ; \mathrm{H}, 4.78 ; \mathrm{N}, 1.12$.

[CIRu(dppm) $\left.{ }_{2}-\mathrm{C} \equiv \mathrm{C}-\mathrm{C}\left(4-\mathrm{NMe}_{2} \mathrm{py}\right)=\mathrm{CH}_{2}\right]^{+} \mathrm{PF}_{6}{ }^{-} \quad$ (3h). From 1 (0.182 g, $0.193 \mathrm{mmol}), \mathrm{KPF}_{6}(0.206 \mathrm{~g}, 1.11 \mathrm{mmol})$, excess butadiyne, and 4-N Me epy $(0.059 \mathrm{~g}, 0.483 \mathrm{mmol}) 0.098$ $\mathrm{g}(41.5 \%)$ of $3 \mathrm{~h}$ was obtained after chromatography $\left(\mathrm{CH}_{2} \mathrm{Cl}_{2} /\right.$ $\mathrm{CH}_{3} \mathrm{CN}, 7.5: 1$ ) as the second, orange band. ${ }^{1} \mathrm{H}$ NMR: $\delta 3.21$ (s, $\left.\mathrm{NCH}_{3}, 6 \mathrm{H}\right), 4.20\left(\mathrm{br}, \mathrm{C}=\mathrm{CHH}, 1 \mathrm{H},{ }^{2} \mathrm{~J}_{\mathrm{H}-\mathrm{H}}=1.5 \mathrm{~Hz}\right), 4.70(\mathrm{~d}$, $\mathrm{C}=\mathrm{CHH}, 1 \mathrm{H},{ }^{2} \mathrm{~J} \mathrm{H}-\mathrm{H}^{2}=1.5 \mathrm{~Hz}$ ), 4.96 (quint, $\mathrm{CH}_{2}(\mathrm{dppm})$, ${ }^{2} \mathrm{P}-\mathrm{H}$ $\left.={ }^{4} \mathrm{p}^{\prime}-\mathrm{H}=4.26 \mathrm{~Hz}, 4 \mathrm{H}\right), 6.25,6.96,(\mathrm{~d}, \operatorname{aryl}-\mathrm{H}($ py), $2 \mathrm{H}, \mathrm{J} \mathrm{H}-\mathrm{H}$ $=7.85 \mathrm{~Hz}), 7.08-7.38(\mathrm{~m}, \operatorname{aryl}-\mathrm{H}(\mathrm{dppm}), 26 \mathrm{H}), 7.45(\mathrm{~m}$, aryl-H (dppm), $14 \mathrm{H}) .{ }^{13} \mathrm{C}\left\{{ }^{1} \mathrm{H}\right\} \mathrm{NMR}\left(\mathrm{CD}_{3} \mathrm{CN}\right): \delta 40.50\left(\mathrm{NMe}_{2}\right)$, 49.21 (quint, $\mathrm{CH}_{2}(\mathrm{dppm}), \mathrm{N}_{\mathrm{P}-\mathrm{C}}=11.0 \mathrm{~Hz}$ ), 53.60 (C3), 103.39 (quint, $\mathrm{C} 2, \mathrm{~J}_{\mathrm{P}-\mathrm{C}}=1.58 \mathrm{~Hz}$ ), 105.05 (quint, 5 $\mathrm{P}-\mathrm{C}=1.05, \mathrm{C}=$ $\mathrm{CH}_{2}$ ), 106.87 (CH (py)), 128.13 (quint, $\mathrm{p}-\mathrm{C}_{6} \mathrm{H}_{5}, \mathrm{~N}_{\mathrm{p}-\mathrm{C}}=2.63 \mathrm{~Hz}$ ), 128.32 (quint, $\mathrm{p}-\mathrm{C}_{6} \mathrm{H}_{5}, \mathrm{~N}_{\mathrm{p}-\mathrm{C}}=2.37 \mathrm{~Hz}$ ), 130.06, $130.13(\mathrm{~m}-$ $\mathrm{C}_{6} \mathrm{H}_{5}$ ), 133.25 (quint, $\mathrm{o}-\mathrm{C}_{6} \mathrm{H}_{5}, \mathrm{~N}_{\mathrm{p}-\mathrm{C}}=3.16 \mathrm{~Hz}$ ), 133.83 (quint, o- $\mathrm{C}_{6} \mathrm{H}_{5}, \mathrm{~N}_{\mathrm{p}-\mathrm{C}}=2.37 \mathrm{~Hz}$ ), 134.15, 135.19 (quint, ipso- $\mathrm{C}_{6} \mathrm{H}_{5}, \mathrm{~N}_{\mathrm{p}-\mathrm{C}}$ $=11.15 \mathrm{~Hz}$ ), $138.58(\mathrm{CH}$ (py)), 145.20 (quint, $\mathrm{Cl}$, J $\mathrm{p}-\mathrm{C}=14.7$ $\mathrm{Hz}), 156.51\left(\mathrm{C}_{\text {ipso }}(\mathrm{py})\right) .{ }^{31} \mathrm{P}\left\{{ }^{1} \mathrm{H}\right\} \mathrm{NMR}: \delta-6.6(\mathrm{~s}, \mathrm{P}(\mathrm{dppm}))$, -143.8 (sept, $\mathrm{PF}_{6}{ }^{-}$, J P-F $\left.=706.3 \mathrm{~Hz}\right)$. IR $(\mathrm{KBr}): \mathrm{v}(\mathrm{C} \equiv \mathrm{C}) 2051$ (m). UV/vis $\left(\mathrm{CH}_{3} \mathrm{CN}\right)\left(\lambda_{\max } \mathrm{nm}(\log \epsilon)\right): 205$ (4.982), 226 (4.855), 265 (4.646), 308 (4.390), 390(sh) (3.643), 495(sh) (3.322), 710 (2.716); $\left(\mathrm{CH}_{2} \mathrm{Cl}_{2}\right) 266$ (4.768), 306 (4.493), 395(sh) (3.734), 520 (sh) 3.395, 720 (2.829). Anal. Calcd for $\mathrm{C}_{61} \mathrm{H}_{56} \mathrm{ClF}_{6} \mathrm{~N}_{2} \mathrm{P}_{5} \mathrm{Ru}$ : C, 59.93; H, 4.62; N, 2.29. Found: C, 59.26; H, 4.48; N, 2.31.

cis-[Ru(dppm) $\left.{ }_{2} \mathbf{C l}\left(\mathrm{NC}_{5} \mathrm{H}_{4} \mathrm{NMe}_{2}-4\right)\right]^{+} \mathrm{PF}_{6}{ }^{-}$(4). 1 (0.163 g, $0.171 \mathrm{mmol}), \mathrm{KPF}_{6}(0.127 \mathrm{~g}, 4$ equiv), and 4-(dimethylamino)pyridine (DMAP, $0.042 \mathrm{~g}, 0.344 \mathrm{mmol}$ ) were suspended in $\mathrm{CH}_{2^{-}}$ $\mathrm{Cl}_{2}$ (35 mL) and stirred under ambient conditions for 3 days. Theyellow solution was filtered from the white precipitate and the solvent removed in vacuo to give a tarry solid. 4-DMAP was removed by washing with toluene $(3 \times 5 \mathrm{~mL})$. The crude, powdery product thus obtained was dried for several hours in vacuo. It was found to contain 4 in $92 \%$ purity, the impurities being 1 and the trans-disubstitution product [Ru(dppm) $)_{2}\left(\mathrm{NC}_{6} \mathrm{H}_{4-}\right.$ $\left.\mathrm{NMe}_{2}\right)^{2+}\left(\mathrm{PF}_{6}{ }^{-}\right)_{2}$. Pure 4 was obtained after recrystallization from cold $\mathrm{CH}_{2} \mathrm{Cl}_{2} / \mathrm{EtOH}$. ${ }^{1} \mathrm{H} \mathrm{NMR}\left(\mathrm{CD}_{3} \mathrm{COCD}_{3}\right): \delta 2.87$ (s, $\left.\mathrm{NCH}_{3}, 6 \mathrm{H}\right), 4.75\left(\mathrm{~m}, \mathrm{CH}_{2}\right.$ (dppm), $\left.1 \mathrm{H}\right), 4.94$ (m, $\mathrm{CH}_{2}(\mathrm{dppm})$, $2 \mathrm{H}), 5.78\left(\mathrm{~d}, \mathrm{CH}(\mathrm{DMAP}),{ }^{2} \mathrm{H}_{\mathrm{H}} \mathrm{H}=7.18 \mathrm{~Hz}\right), 5.88\left(\mathrm{~m}, \mathrm{CH}_{2}\right.$ (dppm), $1 \mathrm{H}), 6.78,6.92$, (m, aryl-H (dppm), 4H), 7.13-7.68 (m, aryl-H (dppm, DMAP), 28H) , 7.77, 8.03, 8.31 (m, aryl-H (dppm), $2 \mathrm{H}) .{ }^{13} \mathrm{C}\left\{{ }^{1} \mathrm{H}\right\} \mathrm{NMR}\left(\mathrm{CD}_{3} \mathrm{COCD}_{3}\right): \delta 38.8\left(\mathrm{NMe}_{2}\right), 40.8$, 43.6 (m, $\mathrm{CH}_{2}$ (dppm), 106.1 (C2 (DMAP), 128.2-136.6 (arene-C

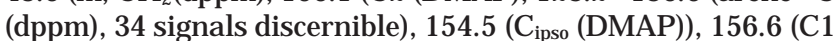
(br, DMAP)). ${ }^{31} \mathrm{P}\left\{{ }^{1} \mathrm{H}\right\} \operatorname{NMR}\left(\mathrm{CD}_{3} \mathrm{COCD}_{3}\right): \delta-25.6$ (ddd, 2 $\mathrm{P}-\mathrm{P}$ (trans) $=326.2,{ }^{2} \mathrm{~J}-\mathrm{P}$ (cis) $\left.=43.0,31.8\right),-20.5$ (ddd, ${ }^{2} \mathrm{P}-\mathrm{P}$ (trans) $=326.2,{ }^{2} \mathrm{~J}$-P(cis) $\left.=29.7,26.5\right),-5.4$ (ddd, ${ }^{2} \mathrm{P}-\mathrm{P}(\mathrm{cis})=31.8,29.7$, 26.3), 0.1 (ddd, ${ }^{2}$ P-P(cis) $=43.0,26.5,26.3$ ) -143.8 (sept, $\mathrm{PF}_{6}{ }^{-}$, $\mathrm{P}-\mathrm{F}=706.3 \mathrm{~Hz}$ ). Anal. Calcd for $\mathrm{C}_{56} \mathrm{H}_{54} \mathrm{ClF}_{6} \mathrm{~N}_{2} \mathrm{P}_{5} \mathrm{Ru}$ : C, 57.96; H, 4.69; N, 2.39. Found: C, 57.20; H, 4.59; N, 2.41 .

Acknowledgment. This work was supported by the Fonds der Chemischen Industrie and the Deutsche Forschungsgemeinschaft. We also wish to thank Mr. Markus Braun for his contribution within an advanced laboratory course, Mr. Matthias Wanner for E PR measurements, and Prof. Dr. Kaim for his continuing support of our research.

Supporting Information Available: Tables of atomic coordinates, isotropic thermal parameters, all bond lengths and bond angles and isotropic displacement parameters (Tables S1-S4) and a packing diagram for $\mathbf{3 a}$ as well as the EPR spectrum of el ectrochemically generated trans- $\left[\mathrm{Cl}(\mathrm{dppm})_{2} \mathrm{Ru}-\right.$ $\left.\mathrm{C} \equiv \mathrm{C}-\mathrm{C}\left(\mathrm{NEt}_{3}\right)=\mathrm{CH}_{2}\right]^{2+}$. This material is available free of charge via the Internet at http://pubs.acs.org.

OM9903240 